\title{
Water-Level Changes in the High Plains Aquifer--Predevelopment to 1992
}

By JACK T. DUGAN, TIMOTHY MCGRATH, AND RONALD B. ZELT

U.S. GEOLOGICAL SURVEY

Water-Resources Investigations Report 94-4027 


\section{U.S. DEPARTMENT OF THE INTERIOR \\ BRUCE BABBITT, Secretary}

U.S. GEOLOGICAL SURVEY

GORDON P. EATON, Director

For additional information write to:

District Chief

U.S. Geological Survey

Room 406 Federal Building

100 Centennial Mall North

Lincoln, NE 68508
Copies of this report can be purchased from:

U.S. Geological Survey

Earth Science Information Center

Open-File Reports Section

Box 25286, MS 517

Denver Federal Center

Denver, Colorado 80225 


\section{CONTENTS}

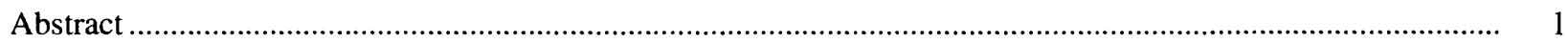

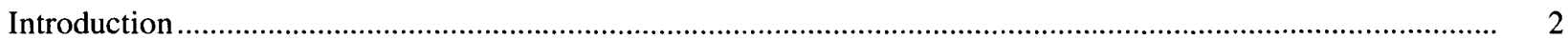

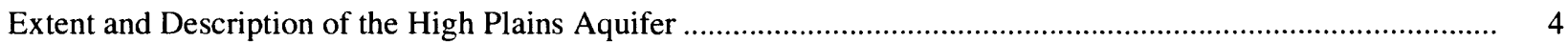

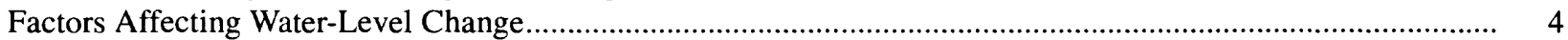

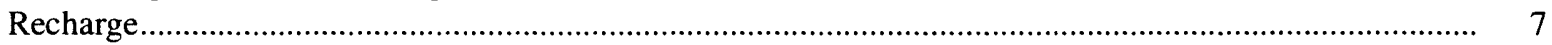

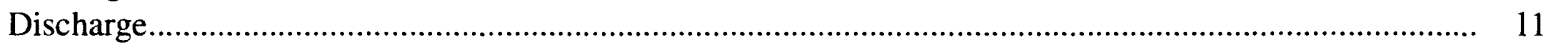

Consumptive Irrigation Requirements in the High Plains ...................................................... 15

Net Water Withdrawals from the High Plains Aquifer .......................................................... 15

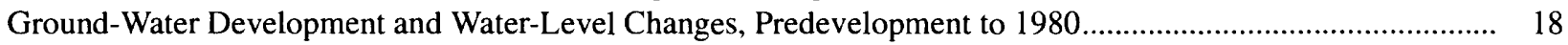

Ground-Water-Level Observation-Well Network ................................................................................. 22

Methods of Data Analysis and Presentation .......................................................................................... 26

Water-Level Change and Precipitation, 1980 to 1992 ........................................................................ 27

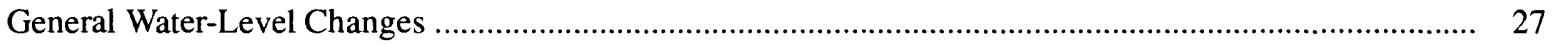

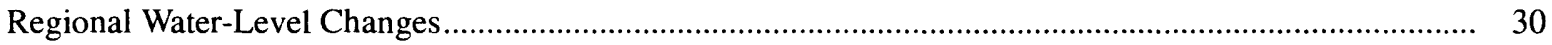

Northern High Plains .............................................................................................. 31

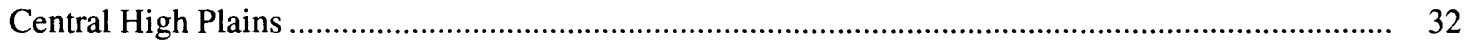

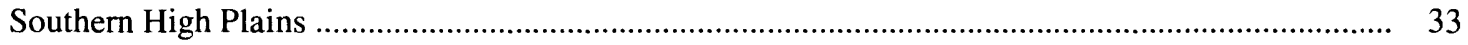

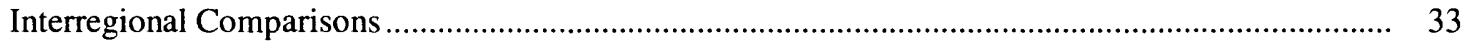

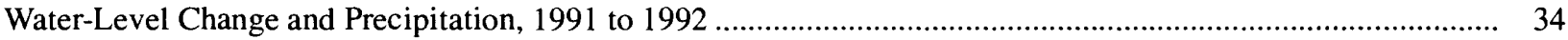

Regional Water-Level Changes..........................................................................................

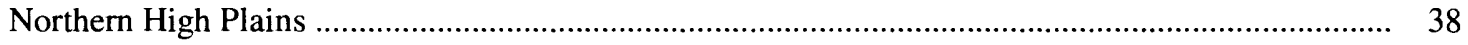

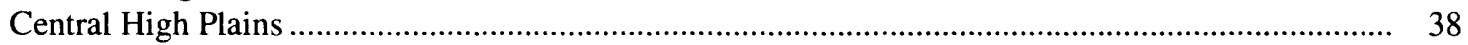

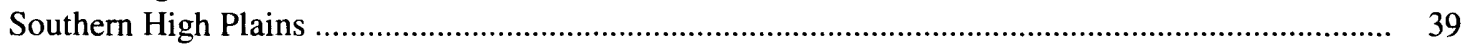

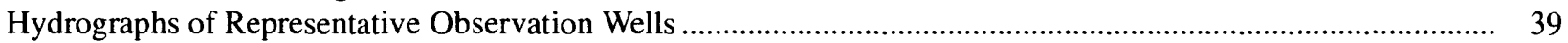

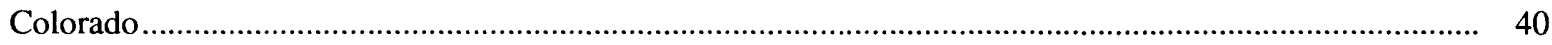

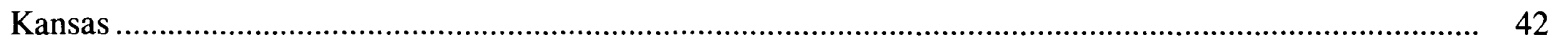

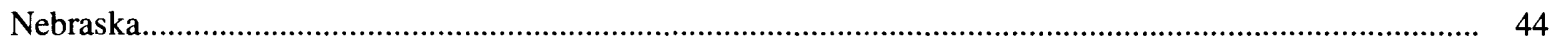

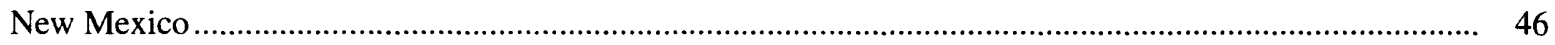

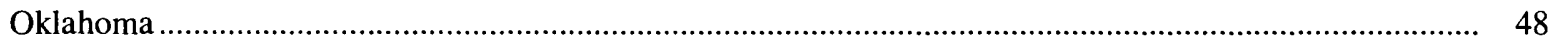

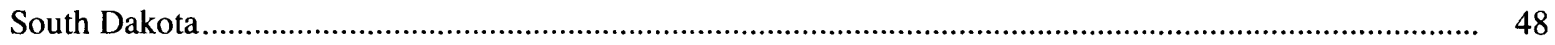

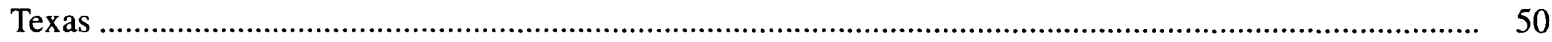

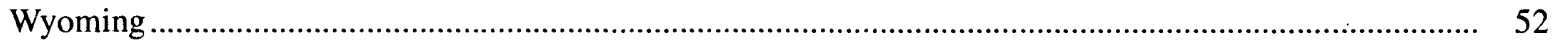

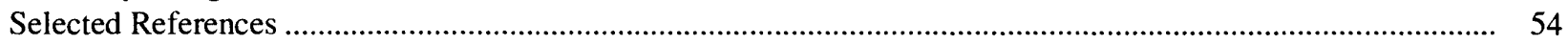


1-14. Maps showing:

1. Regional subdivisions of the High Plains aquifer and location of selected observation wells ........... 3

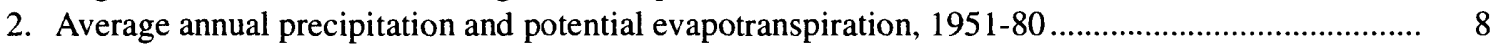

3. Estimated average annual potential ground-water recharge, 1951-80 ............................................. 9

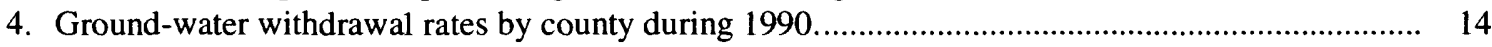

5. Estimated average annual consumptive irrigation requirement for corn, $1951-80 \ldots \ldots \ldots \ldots \ldots \ldots \ldots \ldots \ldots . . .16$

6. Estimated average annual net ground-water withdrawal rate for irrigated corn, 1951-80.............. 17

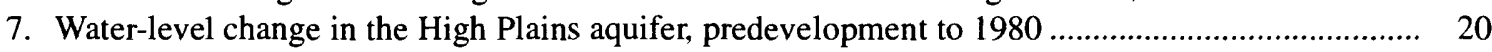

8. Saturated thickness of the High Plains aquifer, 1980 ............................................................. 21

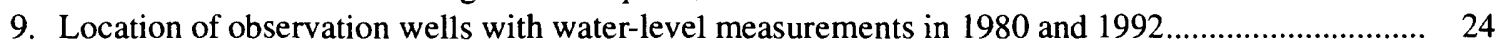

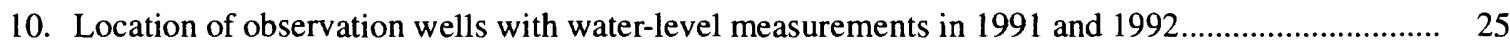

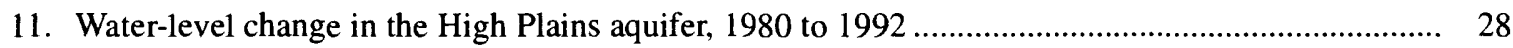

12. Average annual precipitation, 1981-91, and average annual departure from 30 -year normal (1951-80).

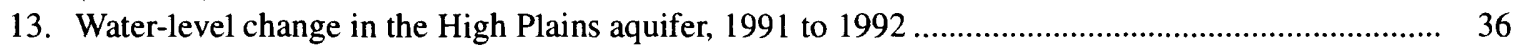

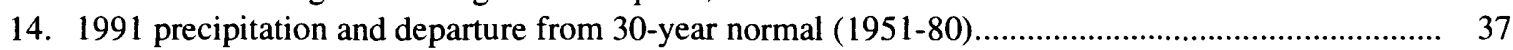

15-22. Hydrographs showing:

15. Water levels in observation wells in: $A$, Yuma County; $B$, Washington County; $C$, Kit Carson County, Colorado.

16. Water levels in observation wells in: $A$, Thomas County; $B$, Finney County; $C$, Sedgwick County, Kansas.

17. Water levels in observation wells in: $A$, Box Butte County; $B$, Chase County; $C$, Seward County, Nebraska

18. Water levels in observation wells in: $A$, Union County; $B$, Curry County, New Mexico .

19. Water levels in observation well in: $A$, Texas County, Oklahoma..

20. Water levels in observation wells in: $A$, Bennett County; $B$, Tripp County, South Dakota

21. Water levels in observation wells in: $A$, Lamb County; $B$, Lubbock County; $C$, Gaines County, Texas (1) 16 17 1 (18) in

22. Water levels in observation wells in: $A$, eastern Laramie County; $B$, southern Laramie County; $C$, Niobrara County, Wyoming

\section{TABLES}

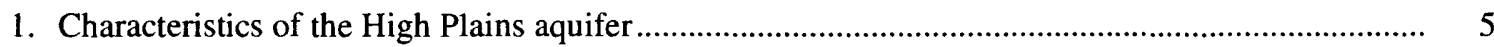

2. Geologic units comprising the High Plains aquifer.......................................................................... 6

3. Ground-water withdrawals from the High Plains aquifer in 1990 and 1985 by type of use............. 13

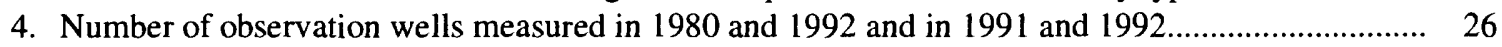

5. Average area-weighted water-level changes and estimated changes in volume of water in storage, predevelopment to 1980 and from 1980 to 1992

6. Area-weighted average annual precipitation during 1981-91 and departure from 30-year normal precipitation (1951-80)

7. Average area-weighted saturated thickness of the High Plains aquifer, predevelopment, 1980, and 1992

8. Comparison of average annual water-level changes and departures of annual precipitation from normal for 1988 to 1992

9. Average area-weighted water-level changes from 1991 to 1992

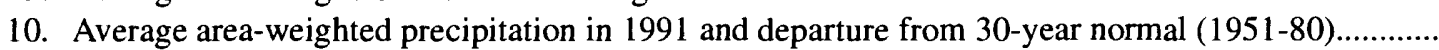




\begin{tabular}{rcl}
\hline Multiply & By & To obtain \\
acre & 0.4047 & hectare \\
acre-foot & 1,233 & cubic meter \\
foot & 0.3048 & meter \\
gallon per minute & 0.06309 & liter per second \\
inch & 25.4 & millimeter \\
mile & 1.609 & kilometer \\
million gallons per day & 0.003785 & million cubic meters per day \\
square mile & 2.590 & square kilometer
\end{tabular}

To convert degree Fahrenheit $\left({ }^{\circ} \mathrm{F}\right)$ to degree Celsius $\left({ }^{\circ} \mathrm{C}\right)$ use the following formula:

$$
{ }^{\circ} \mathrm{C}=5 / 9\left({ }^{\circ} \mathrm{F}-32\right) \text {. }
$$

Sea level: In this report, "sea level" refers to the National Geodetic Vertical Datum of 1929--a geodetic datum derived from a general adjustment of the first-order level nets of the United States and Canada, formerly called Sea Level Datum of 1929. 
VI Water-Level Changes in the High Plains Aquifer--Predevelopment to 1992 


\title{
Water-Level Changes in the High Plains Aquifer-- Predevelopment to 1992
}

\author{
By Jack T. Dugan, Timothy McGrath, and Ronald B. Zelt
}

\section{ABSTRACT}

Regional variability in water-level change in the High Plains aquifer underlying parts of Colorado, Kansas, Nebraska, New Mexico, Oklahoma, South Dakota, Texas, and Wyoming results from large regional differences in climate, soils, land use, and ground-water withdrawals for irrigation. From the beginning of significant development of the High Plains aquifer for irrigation to 1980 , substantial water-level declines have occurred in several areas. The estimated average area-weighted water-level decline from predevelopment (1940) to 1980 for the High Plains was 9.9 feet, which is an average decline of about 0.25 foot per year. Declines exceeded 100 feet in some parts of the Central and Southern High Plains. Declines were much smaller and less extensive in the Northern High Plains, largely as a result of later irrigation development.

Since 1980, water levels in those areas of large declines in the Central and Southern High Plains have continued to decline, but at a slower annual rate. The estimated average area-weighted water-level decline from 1980 to 1992 for the entire High Plains was 2.24 feet, which is an average annual decline of about 0.19 foot. The slower rate of decline since 1980 , in relation to the rates prior to 1980 , is associated with a decrease in groundwater application for irrigated agriculture and greater-than-normal precipitation. Waterconserving practices and technology, in addition to reductions in irrigated acreages, contributed to the decrease in ground-water withdrawals for irrigation. Water-level declines exceeding 20 feet since 1980 , however, are widespread in parts of southwestern Kansas, east-central New Mexico, and the Oklahoma and Texas Panhandles. Widespread declines of 10 to 20 feet and exceeding 20 feet in smaller areas occurred in northeastern Colorado, northwestern Kansas, southwestern Nebraska, and the Nebraska Panhandle from 1980 to 1992. Water-level rises exceeding 20 feet occurred in the extreme Southern High Plains in Texas where precipitation was much greater than normal from 1980 to 1992 . Widespread waterlevel rises of 5 to 10 feet occurred in eastern Nebraska during the same period in association with greater-than-normal precipitation.

The estimated average area-weighted water-level decline from 1991 to 1992 was 0.55 foot, even though the average areaweighted precipitation was well-above normal in 1991 in the High Plains (+1.98 inches). Water-level declines of 3 to 5 feet were widespread in the intensively irrigated areas of the Central and Southern High Plains, particularly southwestern Kansas and the High Plains of Texas. These declines do not appear to be closely related to the 1991 precipitation patterns in these areas. Declines of 1 to 3 feet were common throughout the intensively irrigated areas of the Northern High Plains and the less intensively irrigated areas of the Central and Southern High Plains. Water levels continued to rise, generally 1 to 3 feet, in the extreme southeastern part of the Southern High Plains in Texas. Widely scattered areas of 1- to 3-foot rises also occurred in parts of northeastern and central Nebraska where precipitation was near to slightly greater than normal in 1991. 


\section{INTRODUCTION}

The Omnibus Water Resources Development Act of 1986 (Public Law 99-662) amended the Water Resources Research Act of 1984 (Public Law 98-242). The amendment added a Title III to the legislation, which states in Section 306 that the U.S. Geological Survey (USGS) in cooperation “... with the States of the High Plains region is authorized and directed to monitor the levels of the Ogallala [High Plains] aquifer, and report annually to Congress." Congress recognized that accurate information on the conditions and changes in the High Plains aquifer is necessary to make sound management decisions concerning the use of water, to project future economic conditions, and to conduct hydrologic research pertaining to the High Plains.

The High Plains aquifer (formerly called the Ogallala aquifer) underlies one of the major agricultural areas in the United States (fig. 1). About 20 percent of the irrigated land in the United States is in the High Plains, and about 30 percent of the ground water used for irrigation in the United States is pumped from the High Plains aquifer (Weeks and others, 1988).

Many studies of parts of the aquifer have been completed by irrigation districts, local agencies, State agencies, the USGS, and other Federal agencies. A major study that examined the physical features of the entire aquifer was completed by the USGS. The High Plains Regional Aquifer-System Analysis (High Plains RASA) described the geology and hydrology of the aquifer in detail (Gutentag and others, 1984; Weeks and others, 1988). Computer models for each of three regional subdivisions of the High Plains (fig. 1) were developed during that study to simulate the effects on the aquifer of several proposed watermanagement practices. The analyses made as part of the High Plains RASA were based on data collected before 1981. Beginning in 1988, waterlevel data again were systematically collected and compiled in an aquifer-wide data base (Kastner and others, 1989). The USGS and State and local agencies have compiled water-level data collected since 1980 at more than 12,000 locations.

This report, the fifth in a series, was prepared to fulfill requirements of Section 306, Title III of Public Law 98-242 as amended. It describes the
High Plains aquifer, the factors that affect water levels in the aquifer, the history of aquifer development, water-level changes from predevelopment through the nonirrigation season (generally October through March) of 1979-80 (herein referred to as predevelopment to 1980), water-level changes between the nonirrigation season of 1979-80 and the nonirrigation season of 1991-92 (herein referred to as 1980 to 1992), precipitation patterns from 1981 through 1991 (herein referred to as 1981-91), water-level changes between the nonirrigation seasons of 1990-91 and 1991-92 (herein referred to as 1991 to 1992), and precipitation patterns for 1991 . The changes are shown on maps and are identified in long-term hydrographs of water levels in selected wells.

This report differs somewhat from the previous report in this series (McGrath and Dugan, 1993). Changes in saturated thickness are statistically described in a table in this report. A more complete statistical description of precipitation by time period also is provided in tabular form. An additional illustration has been provided to show observation wells measured in 1980 and 1992.

This report is possible because of the efforts of numerous individuals from local, State, and Federal agencies who have inventoried the well sites, measured the water levels, and processed the data for more than 12,000 locations on an ongoing basis. In addition, the ground-water-data personnel of the USGS in each of the High Plains States have collected and computerized these data from the numerous, diverse sources and analyzed the results for their States. The following USGS personnel serve as the High Plains ground-water data base administrators for their respective States: Colorado, E.R. Banta; Kansas, C.V. Hansen and B.J. Dague; Nebraska, G.V. Steele; New Mexico, R.R. Cruz; Oklahoma, J.E. May; South Dakota, K.M. Neitzert; Texas, S.C. Gandara; and Wyoming, K.A. Miller. High Plains aquifer water-use data were supplied by the following USGS personnel: R.G. Dash, Colorado; L.A. Garrabrant, New Mexico; Z.D. Hill, Nebraska; and H.A. Perlman, Georgia. 


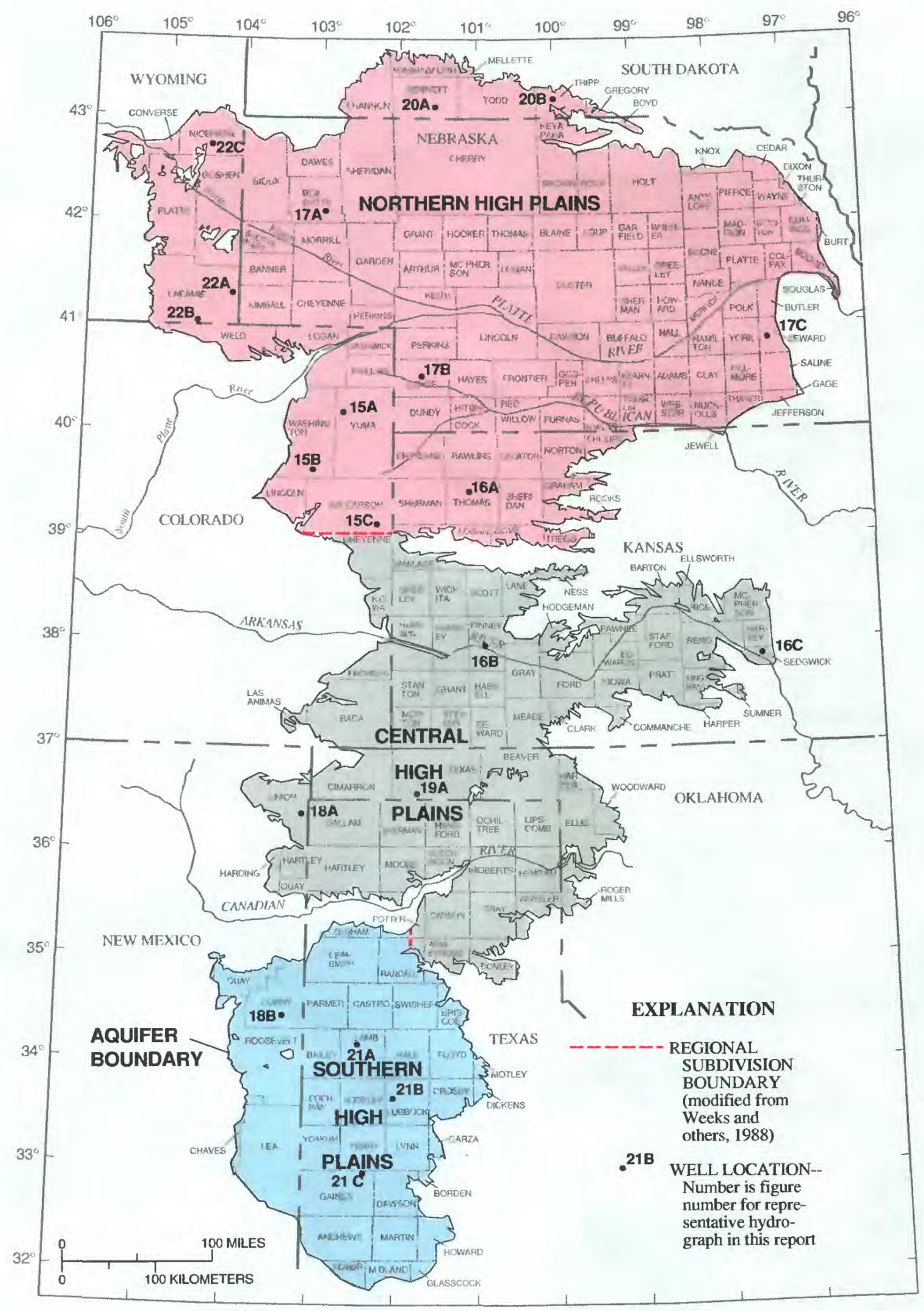

Figure 1. Regional subdivisions of the High Plains aquifer and location of selected observation wells (modified from Dugan and Schild, 1992). 


\section{EXTENT AND DESCRIPTION OF THE HIGH PLAINS AQUIFER}

The High Plains aquifer is an extensive volume of saturated, generally unconsolidated, deposits underlying the High Plains region. This aquifer formerly was known as the Ogallala aquifer, but the different geologic units and ages of the deposits constituting the aquifer necessitated a more inclusive designation. The High Plains aquifer consists mainly of one or more hydraulically connected geologic units of late Tertiary or Quaternary age; the Ogallala Formation is generally the principal unit (Gutentag and others, 1984, p. 8). The High Plains aquifer underlies about 174,050 square miles in parts of Colorado, Kansas, Nebraska, New Mexico, Oklahoma, South Dakota, Texas, and Wyoming (table 1).

The High Plains is a remnant of an alluvial plain that once extended eastward from the ancestral Rocky Mountains. The formation of the plain was followed by periods of uplift, when streams eroded the deposits near the mountain front. This erosion isolated the plain from the mountains in all areas except in the area known as the Gangplank in southeastern Wyoming (Thornbury, 1956, p. 288). In some places the original plain was dissected by eroding streams, but in other areas, Quaternary sediments were deposited on the plain. In much of the Northern High Plains, Quaternary sediments consist of wind-deposited silt, known as loess, and dune sands.

The two oldest geologic units included in the High Plains aquifer are the Brule Formation and Arikaree Group (table 2). The Brule consists mainly of massive well-cemented siltstone. In most areas, the permeability of the Brule is too slight to transmit water in sufficient quantities to provide an economic supply of water to wells and is not considered part of the High Plains aquifer. In parts of Colorado, Wyoming, and western Nebraska, however, the Brule Formation is fractured and yields water in large enough quantities to wells to be considered a part of the High Plains aquifer (Gutentag and others, 1984). The Arikaree Group was deposited after the Brule Formation and consists of massive fine-grained sandstone that generally does not yield large quantities of water. The Arikaree, however, is an important local source of water in parts of the northwestern High Plains in Nebraska, South Dakota, and Wyoming.

The Ogallala Formation was deposited after the Arikaree Group by streams flowing from the ancestral Rocky Mountains. The Ogallala is the principal water-yielding unit of the High Plains aquifer throughout most of the High Plains and is composed of a variety of materials, including clay, silt, sand, and gravel. The Ogallala generally yields large quantities of water to wells.

Sand dunes were formed on the older High Plains deposits in several areas. The most extensive of these areas is the Sand Hills of north-central Nebraska, where the sand deposits in places exceed 300 feet in thickness, and in Kansas south of the Arkansas River. The dunes subsequently were stabilized by vegetation, but major dune formation continued until about 1,500 years before the present (Swinehart, 1989). Where the dune sand is saturated and hydraulically connected to the other units of the High Plains aquifer, it is considered part of the aquifer and generally yields large quantities of water to wells.

During Quaternary time, streams eroded older formations and re-deposited the resulting sediment as valley fill and alluvial material. Present-day streams continue to erode and deposit sediment. Where the stream deposits are saturated and hydraulically connected to the other units of the High Plains aquifer, they are considered to be part of the High Plains aquifer.

The deposits of Quaternary age are widespread and are locally important sources of water. However, only in Kansas, Nebraska, and New Mexico are the Quaternary deposits an areally substantial part of the High Plains aquifer. The intensive irrigation in the Platte River Valley of central Nebraska is based largely on ground water exclusively from Quaternary deposits (Peckenpaugh and Dugan, 1983; Peckenpaugh and others, 1987).

\section{FACTORS AFFECTING WATER-LEVEL CHANGE}

If the High Plains aquifer were unaffected by human activities, it would be in a state of equilibrium in which natural discharge from the 


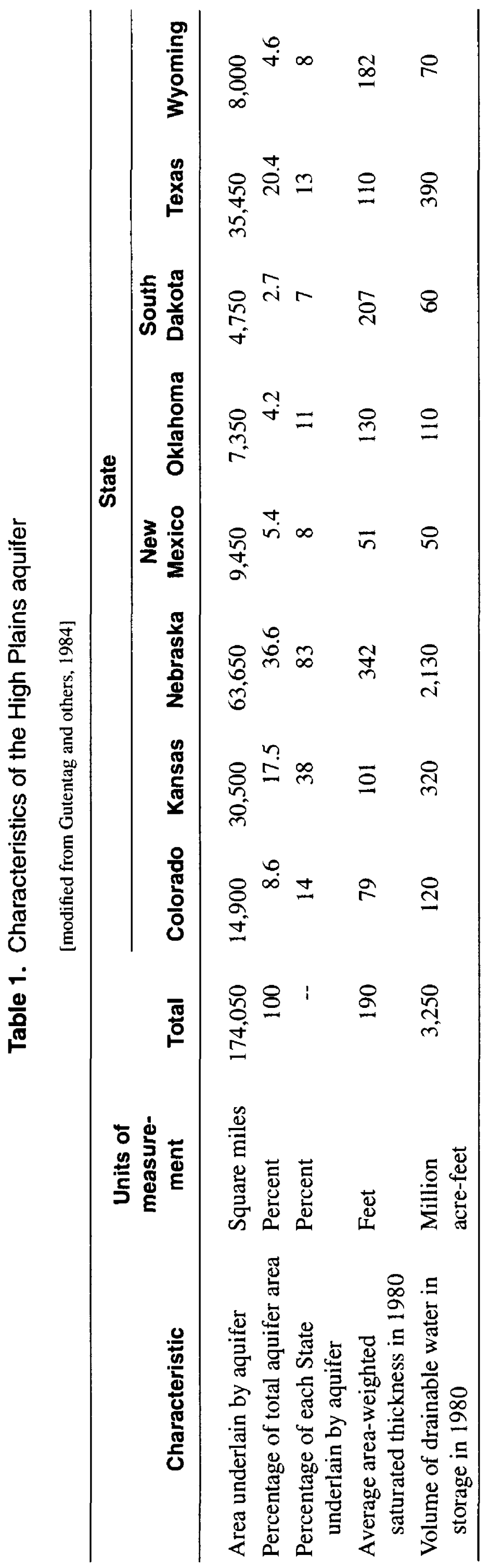




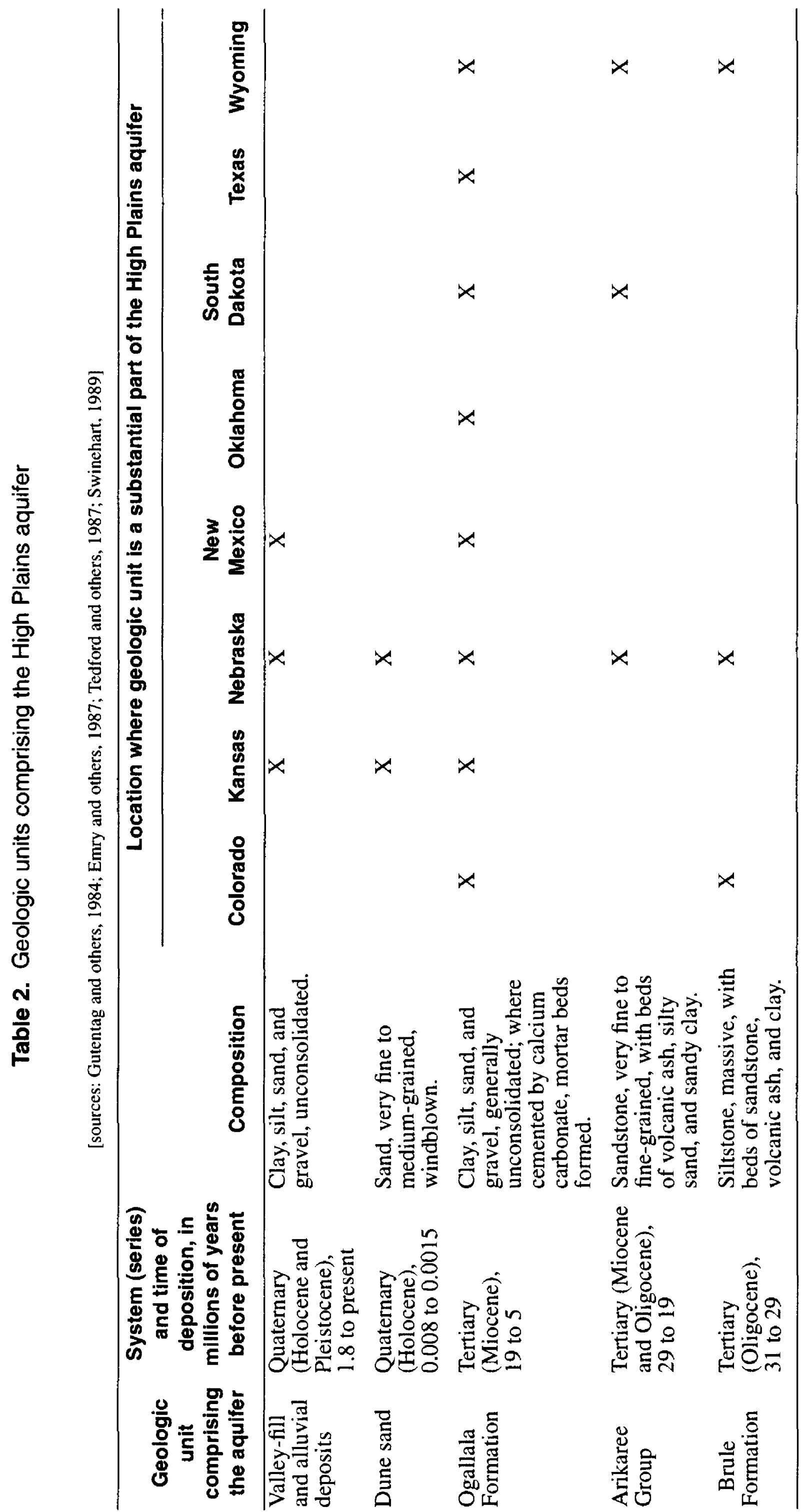


aquifer would be approximately equal to natural recharge to the aquifer. Water levels would be generally stable under these conditions. However, activities such as pumpage from wells, surfacewater diversions for irrigation and hydroelectricpower generation, and cultivation and grazing practices result in nonequilibrium in the aquifer; discharge does not equal recharge in many areas. This nonequilibrium results in substantial changes in ground-water levels.

\section{Recharge}

Precipitation is the principal source of natural ground-water recharge in the High Plains. In a few areas, however, natural recharge can result from seepage losses from streams and lakes. This recharge is particularly important along parts of the Platte River system in Colorado, Nebraska, and Wyoming, where substantial seepage losses of streamflow originating outside the High Plains result in recharge to the High Plains aquifer. This recharge process has contributed to a degree of stability of water levels in parts of central Nebraska. Recharge from infiltration of water lost by seepage from surface-water diversions for irrigation and hydroelectric-power generation has caused water levels to rise in a few areas of the High Plains, particularly in south-central Nebraska.

Recharge from precipitation is quite variable in the High Plains, both in time and in space. Factors that affect this variability include the precipitation regime, evapotranspiration, soils, vegetation, land-use practices, and the characteristics of the unsaturated zone between the soil zone and water table. These factors determine how much of the precipitation reaches the aquifer. The relation among these factors also makes the process of recharge from precipitation complex and dynamic. The basic concept of ground-water recharge from precipitation is expressed in an equation (Dugan and Peckenpaugh, 1985) describing the soil-water balance:

$$
\mathrm{R}=\mathrm{P}+\mathrm{S}-\mathrm{O}-\mathrm{E}-\mathrm{C}
$$

where $\mathrm{R}=$ recharge, in inches;

$P=$ precipitation, in inches;

$$
\begin{aligned}
\mathrm{S}= & \text { antecedent soil water (stored), in } \\
& \text { inches; } \\
\mathrm{O}= & \text { surface runoff, in inches; } \\
\mathrm{E}= & \text { actual evapotranspiration, in inches; } \\
& \text { and } \\
\mathrm{C}= & \text { water-storage capacity of the soil zone, } \\
& \text { in inches. }
\end{aligned}
$$

The nonuniform distribution of precipitation, both in time and space, probably causes most of the variability in recharge to the High Plains aquifer. Average annual precipitation ranges from about 14 inches in the extreme western High Plains to about 30 inches in parts of eastern Nebraska and central Kansas (fig. 2). About 75 percent of the annual precipitation normally occurs during the warm season, April through September. Much of the precipitation during this season comes from local thunderstorms, which can cause variable patterns of precipitation, irrigation requirements, and recharge in a small area during a given time period. Recharge, however, is dependent mostly on cool-season precipitation (October through March) when evapotranspiration is less. Although areal variability in precipitation generally is less localized in the cool season than in the warm season, cool-season precipitation amounts can vary substantially from year to year.

The amount of water in the soil that becomes available for recharge is dependent largely on evapotranspiration. Potential evapotranspiration (fig. 2) is the maximum water loss that would occur by evaporation and transpiration from an area with complete vegetative cover, provided that an adequate supply of soil water is available at all times to meet vegetation demands. Potential evapotranspiration is determined by the amount of atmospheric energy available for the removal of water from the soil either directly as evaporation or as transpiration from vegetation. Potential evapotranspiration is dependent on various climatic and atmospheric elements that include solar radiation, temperature, humidity, and wind velocity. The increase in potential evapotranspiration from northeast to southwest across the High Plains is a consequence of (1) an increase in solar radiation, (2) an increase in temperature, (3) a decrease in humidity, and (4) an increase in wind velocity. Actual evapotranspiration is further dependent on the type of vegetation, length of the growing season, and the availability of soil water. 


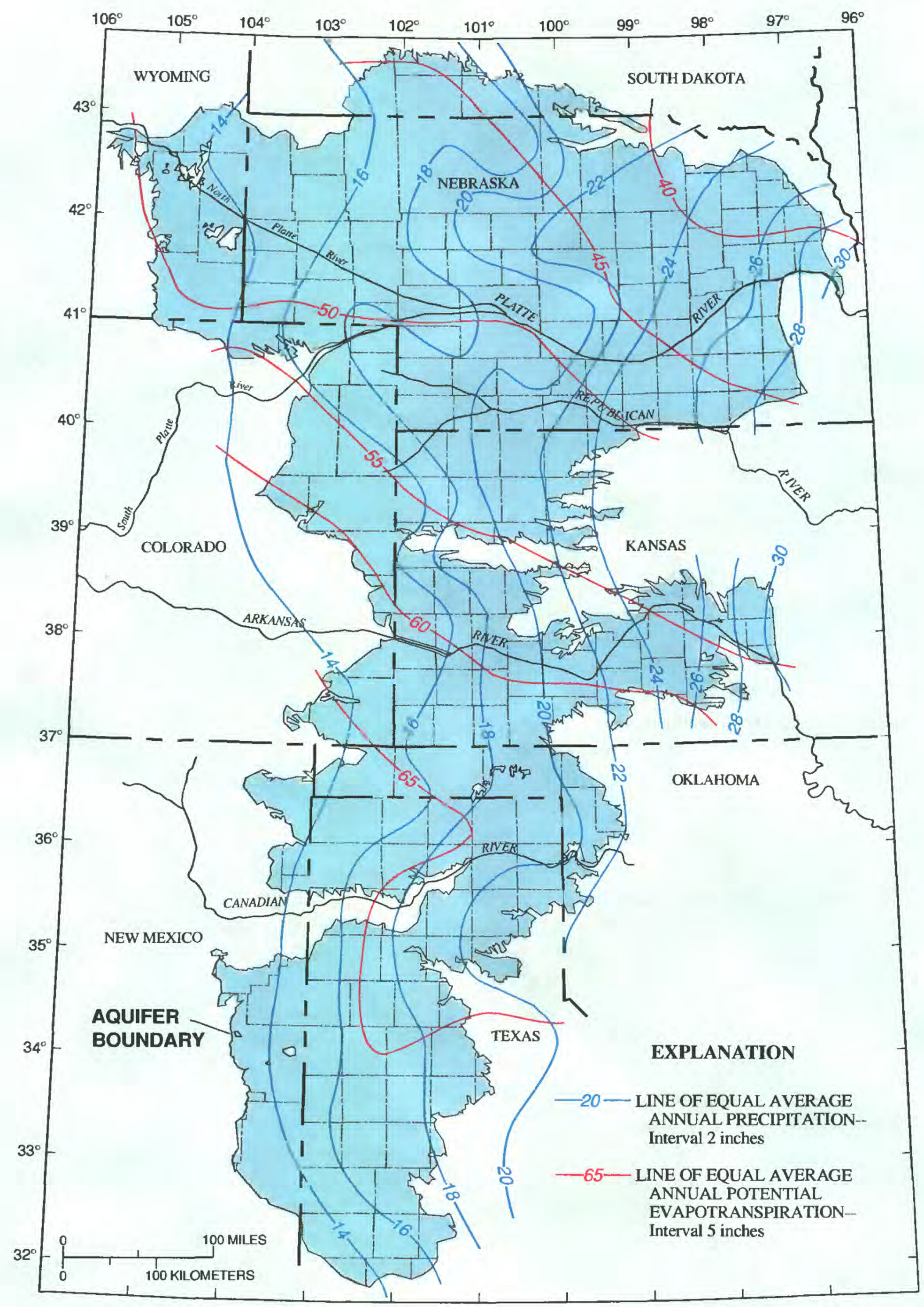

Figure 2. Average annual precipitation and potential evapotranspiration, 1951-80 (Dugan and Zelt, in press). 


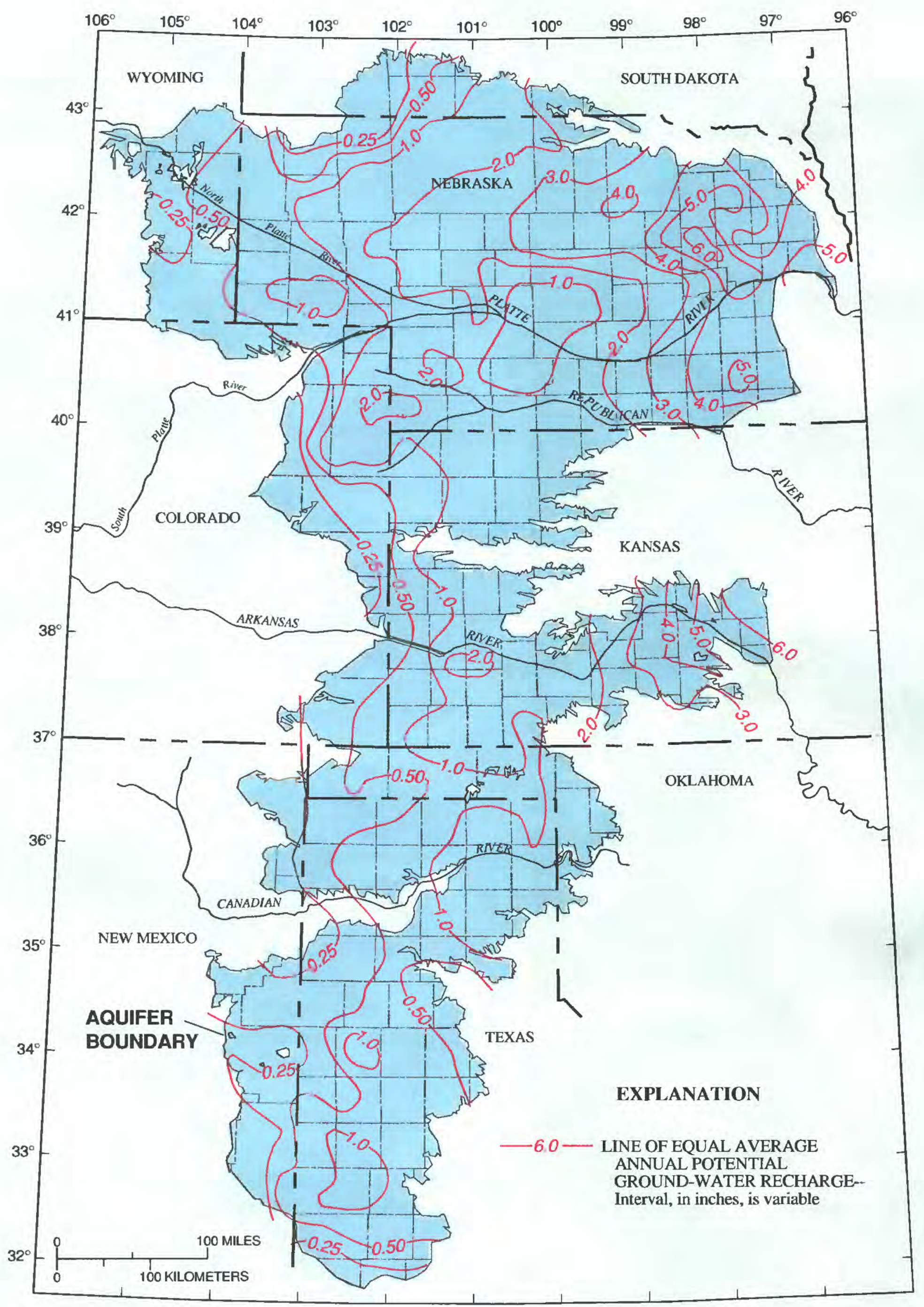

Figure 3. Estimated average annual potential ground-water recharge, 1951-80 (modified from Dugan and Zelt, in press). 
The seasonal relation of precipitation to evapotranspiration strongly affects the recharge process. In the High Plains, recharge occurs mostly during the nongrowing season, when evapotranspiration is minimal and soil water can accumulate in the root zone and percolate downward. This accumulative process may extend throughout the nongrowing season with lateautumn precipitation remaining in the soil column through the winter and percolating downward out of the root zone only after spring precipitation and winter snowmelt cause the soil's available water capacity to be exceeded. Thus, antecedent soilwater conditions, winter snow, early-spring precipitation prior to the onset of the growing season, and evapotranspiration are critical to recharge during the nongrowing season.

The hydrologic characteristics of the soils can have a significant effect on recharge and resultant water-level change. Sandy soils permit greater recharge than finer textured soils. Under equivalent vegetative and climatic conditions, recharge can be several times larger for sandy soils than for silty clay-loam soils as a result of the sandy soil's smaller available water capacity and greater permeability (Dugan and Zelt, in press). Slope also affects the rate at which precipitation infiltrates the soil and becomes soil water. Steeply sloping soils with silty-clay loam texture, common in parts of the High Plains, are characterized by large overland runoff and small infiltration during moderateto high-intensity rainfall. A more complete discussion and generalized map of the hydrologic characteristics of soils and their effects on recharge in the High Plains are found in Dugan and others (1990).

Recharge also is affected by vegetation type. Each vegetation type has a characteristic consumptive water requirement (the amount of soil water that vegetation would use, if available), which ultimately affects the soil water available for recharge and irrigation needs. Therefore, variability of vegetation types across the High Plains affects patterns of water-level change.

Various government programs to remove cropland from production, including the U.S.

Department of Agriculture's Conservation Reserve Program, which was implemented in 1986 as part of the Food Security Act, have resulted in changes in vegetation patterns in the High Plains. Under the
Conservation Reserve Program, cropland is returned to grassland or forest land for a minimum of 10 years. Although the conversion of cropland to grassland in the High Plains could result in a decrease in recharge because of the larger consumptive water requirement for grasses than for most cultivated crops (Dugan and Zelt, in press), the resulting effects on water levels likely will be more than offset by the opposing effects of decreases in ground-water withdrawals for irrigation as a result of these conversions from irrigated agriculture to nonirrigated uses.

Intensity of cultivation, cropping practices, and methods of tillage and land management can have a substantial effect on recharge. Because consumptive water requirements of most cultivated crops are less than that of native grasses, recharge in those areas of intensive cultivation is considerably enhanced. These areas include eastern and central Nebraska, central and southwestern Kansas, and parts of the Texas Panhandle. In parts of the western High Plains where winter wheat-fallow rotation is practiced, more than 25 percent of the land may be fallow in any given year. Fallow conditions increase recharge by decreasing transpiration of soil water from cropland. Certain methods of tillage and land management can increase recharge by limiting water losses from runoff and evaporation. Infiltration of soil water is increased by minimum tillage, land leveling for gravity and flood irrigation, and terracing (Dugan and Zelt, in press).

Estimated potential recharge to the High Plains aquifer during 1951-80 (fig. 3) is calculated by the soil-water balance method expressed in equation 1 and more fully in Dugan and Zelt (in press). The values shown in figure 3 are not the observed amounts of water entering the aquifer but are values for the surplus soil water available as recharge as determined by the climatic, soil, and vegetation characteristics discussed above. Furthermore, potential recharge does not consider the process of soil water moving beyond the soil zone through the unsaturated zone to the aquifer. This latter process may occur within a few hours or through many months, depending on the depth to the water table and the characteristics of the geologic materials in the unsaturated zone between the soil zone and the water table. 
The relation between precipitation (fig. 2) and estimated potential recharge (fig. 3) is apparent. Estimated average annual potential recharge amounts range from about 25 percent of the average annual precipitation in eastern Nebraska to less than 0.5 percent in the western parts of the High Plains. Generally, where average annual precipitation exceeds 24 inches in the High Plains, the estimated average annual potential recharge exceeds 4 inches. Potential recharge exceeds 6 inches in parts of eastern Nebraska and central Kansas, where the soils are sandy and precipitation exceeds 25 inches. In parts of the far western High Plains, however, where precipitation is less than 16 inches, evapotranspiration generally exceeds 60 inches, and soils are fine textured, estimated average annual potential recharge is less than 0.25 inch (Dugan and Zelt, in press). Estimates of annual recharge of 6 inches and 0.25 inch in these areas, respectively, by Weeks and others (1988) compare well with those of Dugan and Zelt (in press).

Although the effect of precipitation on estimated potential recharge is evident, other factors also are important in defining local recharge patterns. Estimated recharge that is large for the existing climatic conditions in parts of northcentral and southwestern Nebraska, northeastern Colorado, south-central Kansas, and western Texas is largely attributable to sandy soils (Dugan and others, 1990; Dugan and Zelt, in press).

Agricultural practices also affect local patterns of potential recharge in the High Plains. Rates of potential recharge are increased in the southern Nebraska Panhandle, most of the Kansas High Plains, northeastern Colorado, and parts of the Oklahoma and Texas Panhandles as a result of large areas of fallow land associated with winter wheat. Potential recharge also is increased substantially in eastern and central Nebraska, central and southwestern Kansas, and parts of the Texas Panhandle where other crops largely have replaced native grasslands (Dugan and Zelt, in press).

Average annual potential recharge shown in figure 3 does not indicate the large variability in recharge through time. Recharge throughout the High Plains may vary considerably from year to year, principally because of variations in precipitation. In many years recharge may not occur in areas where annual precipitation generally is small.
Most of the long-term average recharge can result from a few short, wet periods. The recharge process commonly is cyclical in the High Plains-- 2 or more consecutive years in which conditions are favorable for recharge, followed by several years when these conditions are not present and recharge is negligible.

\section{Discharge}

Water is discharged from the High Plains aquifer both naturally and artificially. Natural discharge from the aquifer occurs as evapotranspiration from plants and soil where the water table is near the land surface and as seepage from the aquifer through springs and to streams where the water table intersects the land surface. Long-term natural discharge would tend to balance long-term natural recharge. Water is artificially discharged from the aquifer predominantly by pumping from wells. Artificial discharge can cause an imbalance in the recharge-discharge relation in the aquifer; when discharge exceeds recharge, some water is removed from storage. Part of the imbalance can be offset by a decrease in natural discharge or an increase in induced recharge from streams caused by the lowering of the water table.

Comprehensive data on the withdrawal and use of water from the High Plains aquifer are collected and published at 5-year intervals by the USGS in cooperation with State and local agencies (Solley and others, 1993). Some of these data are derived from records of metered wells; however, most water withdrawn from the High Plains aquifer is from wells that are not metered, particularly those used for withdrawal of water for irrigation, rural domestic consumption, and livestock. Estimated irrigation pumpage is extrapolated from (1) available metered pumpage and (2) computations of pumpage based on consumptive irrigation requirements, acreages of irrigated crops, and irrigation efficiency data. Rural domestic water use and livestock consumption are extrapolated from average consumption per capita and per head of livestock for a known population and number of livestock, respectively.

Withdrawals from the High Plains aquifer declined between both 1980 and 1985 and 1985 and 1990. The estimated total volume of water 
withdrawn from the High Plains aquifer was 20,519,000 acre-feet in 1980 (Wayne Solley, U.S. Geological Survey, oral commun., 1988), $17,071,500$ acre-feet in 1985 , and 16,534,800 acrefeet in 1990 (table 3). Thus, withdrawals decreased about 17 percent between 1980 and 1985 and about 3 percent between 1985 and 1990. The 3 -percent decrease in total withdrawals between 1985 and 1990 was due largely to a nearly 4-percent decrease in water withdrawals for irrigation and livestock use during that period. Although comparable livestock water-use data are not available for 1985, available data indicates livestock water use probably increased slightly from 1985 to 1990 (Carr and others, 1990; Solley and others, 1993). Thus, the decrease in total agricultural water use was attributable almost entirely to decreases in irrigation water use. Nonagricultural water uses increased about 15 percent between 1985 and 1990 (table 3). Further comparison of changes in nonagricultural water uses between 1985 and 1990 is not possible because of differences in water-use classification.

The ground-water withdrawal statistics in table 3 apply only to individual years, which are not necessarily representative of long-term water use. Withdrawals, particularly for irrigation, are affected by climatic conditions, particularly precipitation, which can cause large fluctuations in water requirements. None of the water-use reporting years--1980, 1985, and 1990--appear to represent extraordinary precipitation conditions in the High Plains. Some of the decreases in withdrawals between 1980 and 1985, however, are attributable to precipitation increases and, consequently, smaller irrigation requirements in parts of the High Plains in 1985, particularly in Nebraska (Steele, 1988). The apparent 10-year decline in total ground-water withdrawals from the High Plains aquifer largely is a result of reduction in withdrawals for irrigation. This reduction is a result of several factors, including:

(1) Climatic conditions since 1980 have been conducive to decreased water demands. Prolonged droughts generally were absent from 1980 to 1991 in most of the major irrigated areas of the High Plains. Precipitation was above normal in nearly all parts of the High Plains in 1981-91, averaging nearly 2 inches above normal.
(2) There has been a long-term decrease in the amount of irrigated cropland in parts of the High Plains. In Texas, the irrigated land in the High Plains decreased by 1.39 million acres or about 31 percent between 1979 and 1991 (Gutentag and others, 1984; Dugan and Schild, 1992, p. 44). In the remaining High Plains States, the amount of acres irrigated either have stabilized or have decreased since the late 1970's or early 1980's (Kastner and others, 1989; Dugan and Schild, 1992). Stable or declining agricultural commodity prices and increased irrigation and other production costs since the late 1970's have made irrigation of crops only marginally profitable. Increased costs due to declining water tables and increased energy prices have reduced the profit margin on irrigated land. In some areas, the number of irrigated acres has declined because reduced saturated thickness of the aquifer has reduced well yields.

(3) Improved agricultural management practices have reduced the volume of water needed to meet consumptive irrigation requirements of crops. These practices include widespread use of minimum-tillage methods, more precise irrigation scheduling and application rates through monitoring of soil-water conditions, technological and operational improvements in irrigation delivery systems, and improved plant varieties that utilize available soil water more efficiently.

Kansas, Nebraska, and Texas, which have nearly 75 percent of the land area overlying the High Plains aquifer (table 1), accounted for about 85 percent of both the total withdrawals and withdrawals for irrigation from the High Plains aquifer in 1990 (table 3). Three major areas of large withdrawal rates occur in the High Plains:

(1) eastern and south-central Nebraska;

(2) southwestern and south-central Kansas; and

(3) the northern part of the Southern High Plains in Texas and New Mexico (fig. 4). Areas with slightly smaller withdrawal rates include an area encompassing northeastern Colorado, southwestern Nebraska, west-central Kansas, and the northwestern Panhandle of Texas. In all of these areas, the saturated thickness of the aquifer, well yields, soils, and topography are conducive to irrigated agriculture.

The ground-water withdrawals rates by county shown in figure 4 principally represent irrigation 
Table 3. Ground-water withdrawals from the High Plains aquifer in 1990 and 1985 by type of use [withdrawals in thousands of acre-feet]

\begin{tabular}{|c|c|c|c|c|c|c|}
\hline \multirow[b]{2}{*}{ State } & \multirow[b]{2}{*}{ Year } & \multicolumn{2}{|c|}{ Nonagricultural use } & \multicolumn{2}{|c|}{ Agricultural use } & \multirow[b]{2}{*}{ Total } \\
\hline & & \multicolumn{2}{|c|}{$\begin{array}{cc} & \begin{array}{c}\text { Mining, } \\
\text { industrial, } \\
\text { commercial, }\end{array} \\
\text { Domestic } & \text { and } \\
\text { (public and } & \text { thermo- } \\
\text { private } & \text { electric- } \\
\text { water } & \text { power } \\
\text { supplies) } & \text { generation }\end{array}$} & Livestock & Irrigation & \\
\hline \multirow[t]{2}{*}{ Colorado } & 1990 & 11.6 & 5.5 & 8.6 & 989.5 & $1,015.2$ \\
\hline & 1985 & \multicolumn{2}{|c|}{ - } & \multicolumn{2}{|c|}{ 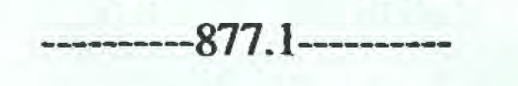 } & 883.3 \\
\hline \multirow[t]{2}{*}{ Kansas } & 1990 & 54.4 & 19.4 & 51.6 & $3,936.6$ & $4,062.0$ \\
\hline & 1985 & \multicolumn{2}{|c|}{ 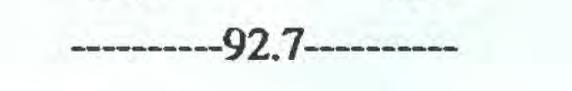 } & \multicolumn{2}{|c|}{-4,324.0 } & $4,416.7$ \\
\hline \multirow[t]{2}{*}{ Nebraska } & 1990 & 167.7 & 19.7 & 101.4 & $4,736.4$ & $5,025.2$ \\
\hline & 1985 & \multicolumn{2}{|c|}{ 197.1 } & \multicolumn{2}{|c|}{-5,598.5 } & $5,795.6$ \\
\hline \multirow[t]{2}{*}{ New Mexico } & 1990 & 29.0 & 22.5 & 4.2 & 738.4 & 794.1 \\
\hline & 1985 & \multicolumn{2}{|c|}{-50.0- } & \multicolumn{2}{|c|}{-603.0 } & 653.0 \\
\hline \multirow[t]{2}{*}{ Oklahoma } & 1990 & 17.3 & 0.9 & 13.0 & 375.3 & 406.5 \\
\hline & 1985 & \multicolumn{2}{|c|}{$8.0-1$} & \multicolumn{2}{|c|}{270.0} & 278.0 \\
\hline \multirow[t]{2}{*}{ South Dakota } & 1990 & 2.9 & 0 & 1.2 & 18.3 & 22.4 \\
\hline & 1985 & \multicolumn{2}{|c|}{ - } & \multicolumn{2}{|c|}{-21.7- } & 24.7 \\
\hline \multirow[t]{2}{*}{ Texas } & 1990 & 106.5 & 194.0 & 47.9 & $4,702.4$ & $5,050.8$ \\
\hline & 1985 & \multicolumn{2}{|c|}{ 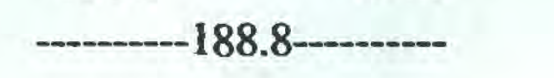 } & \multicolumn{2}{|c|}{ - 4,531.7 } & $4,720.5$ \\
\hline \multirow[t]{2}{*}{ Wyoming } & 1990 & 11.8 & 0.5 & 1.3 & 145.0 & 158.6 \\
\hline & 1985 & \multicolumn{2}{|c|}{ 33.0-3 } & \multicolumn{2}{|c|}{ 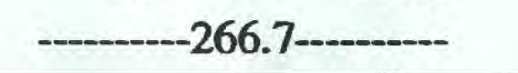 } & 299.7 \\
\hline \multirow[t]{2}{*}{ Total } & 1990 & 401.2 & 262.5 & 229.2 & $15,641.9$ & $16,534.8$ \\
\hline & 1985 & \multicolumn{2}{|c|}{ 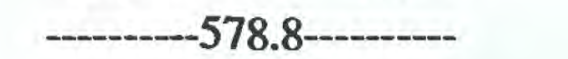 } & \multicolumn{2}{|c|}{$16,492.7$} & $17,071.5$ \\
\hline
\end{tabular}




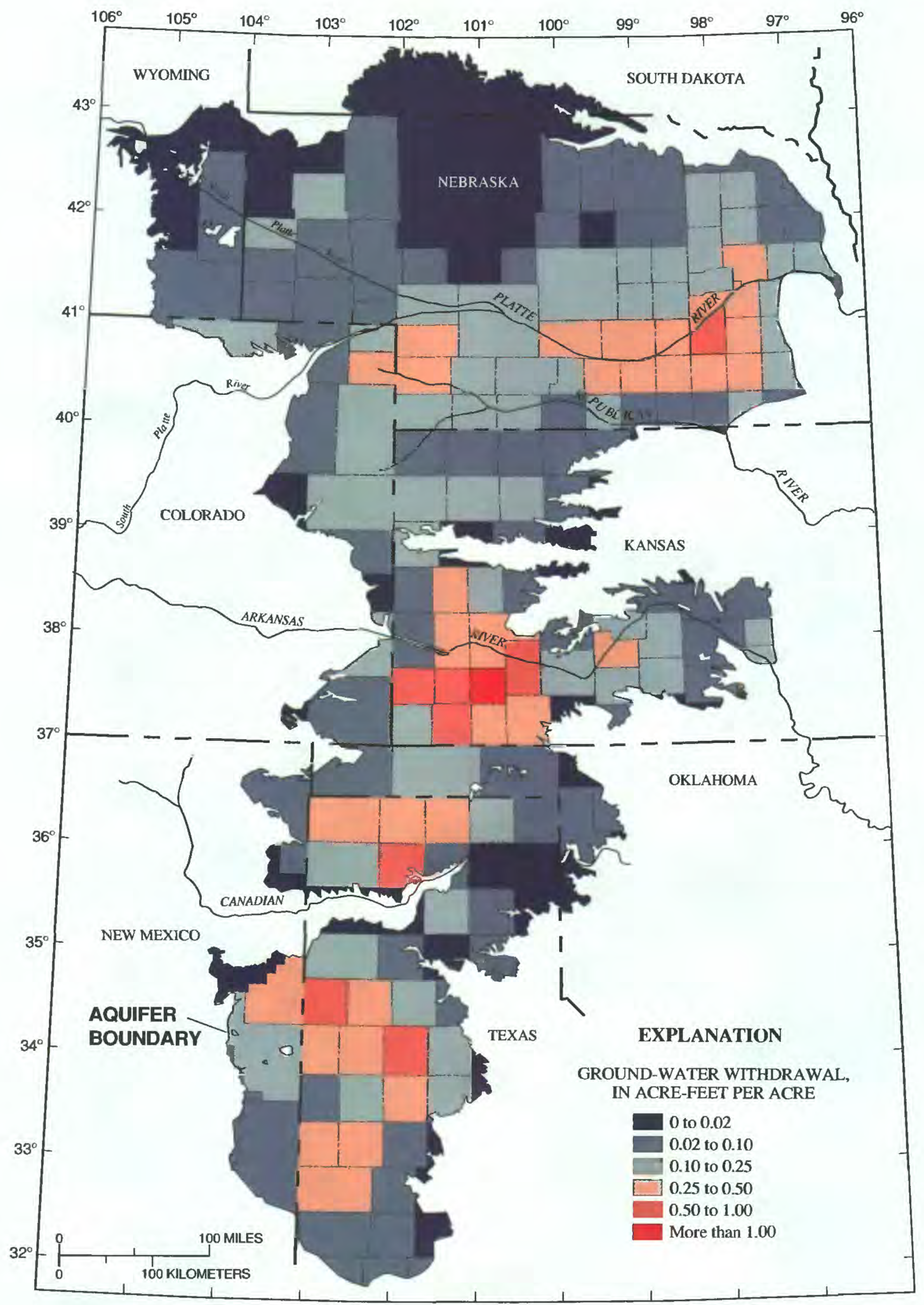

Figure 4. Ground-water withdrawal rates by county during 1990 (data from U.S. Geological Survey National Water-Data Storage and Retrieval System). 
development because ground-water irrigation accounted for about 95 percent of all ground-water withdrawals in the High Plains in 1990 (table 3). Thus the withdrawal rates (fig. 4) are largely a function of both irrigated acreages in the county and withdrawal rates per irrigated acre. The large withdrawal rates per county in parts of southwestern Kansas and the Texas Panhandle reflect, in part, the large withdrawal rates per irrigated acre in these areas. Some counties in south-central Nebraska have among the largest percentage of area irrigated in the High Plains, but withdrawal rates per irrigated acre are relatively small in this area (Dugan and Zelt, in press). Ground-water withdrawals from the High Plains aquifer in 1990 ranged from less than 0.02 acre-foot per acre $(0.25 \mathrm{inch})$ in areas of minimal ground-water development to more than 1.0 acre-foot per acre (12 inches) in Haskell County in southwestern Kansas (figs. 1 and 4).

Ground-water withdrawals for irrigated crops do not represent the actual consumption or water permanently removed from the aquifer. Only that water consumed by evapotranspiration or that which runs off into drainage ways is actually lost. Because runoff generally is minimal for most irrigation systems currently in use and because the volume of water applied to crops often exceeds evapotranspiration, a substantial volume of the applied water may infiltrate through the soil and unsaturated zones and return to the aquifer as recharge. Thus, ground-water withdrawals alone do not fully explain water-level changes.

\section{Consumptive Irrigation Requirements in the High Plains}

The consumptive irrigation requirement provides an estimate of the volume of water consumed by irrigated crops through evapotranspiration and, therefore, actually lost from the aquifer. It is an estimate of the minimum irrigation water required to maintain adequate soil water for optimal plant growth. This requirement, which is unique for each crop, is dependent largely on (1) potential evapotranspiration, (2) the growth characteristics of the crop, (3) soil water available at the beginning of the irrigation season, and (4) irrigation-season precipitation. The hydrologic characteristics of the soil have only a limited effect on the consumptive water requirement of a specific crop (Dugan and Zelt, in press).

The consumptive irrigation requirement does not represent a minimum pumpage requirement, which assumes some inefficiencies in irrigationdistribution systems. The consumptive irrigation requirement as an estimate of water lost from the aquifer is based on the assumption that irrigation efficiency is 100 percent and that any excess water applied either becomes runoff (usually negligible) or infiltrates back to the aquifer.

Average annual consumptive water requirements during 1951-80 for corn, the principal irrigated crop in the High Plains, ranged from about 8 inches in northeastern Nebraska to about 22 inches in northeastern New Mexico (fig. 5). The combination of larger average annual potential evapotranspiration and smaller average annual precipitation caused the largest consumptive water requirements to occur in the southwestern part of the Central High Plains. Average annual consumptive irrigation requirements in areas of substantial irrigation ranged from 8 to 16 inches in Nebraska, 15 to 20 inches in southwestern Kansas, and 15 to 21 inches in the Texas Panhandle.

\section{Net Water Withdrawals from the High Plains Aquifer}

Water-level declines in areas of the High Plains irrigated with ground water should reflect the net withdrawals of water from the aquifer. Actual net withdrawals can be expressed in the following equation:

$$
W_{n}=I_{p}-\left(S_{i}+R\right),
$$

where

$$
\begin{aligned}
W_{n}= & \text { net ground-water withdrawals, } \\
I_{p}= & \text { irrigation pumpage, } \\
S_{i}= & \text { seepage of excess irrigation water back } \\
& \text { to aquifer, and } \\
R= & \text { recharge from precipitation. }
\end{aligned}
$$

Observed data for irrigation pumpage $\left(I_{p}\right)$, seepage $\left(S_{\mathrm{i}}\right)$, and recharge $(R)$, however, are not available. An alternative method of estimating net withdrawals is expressed in the following equation: 


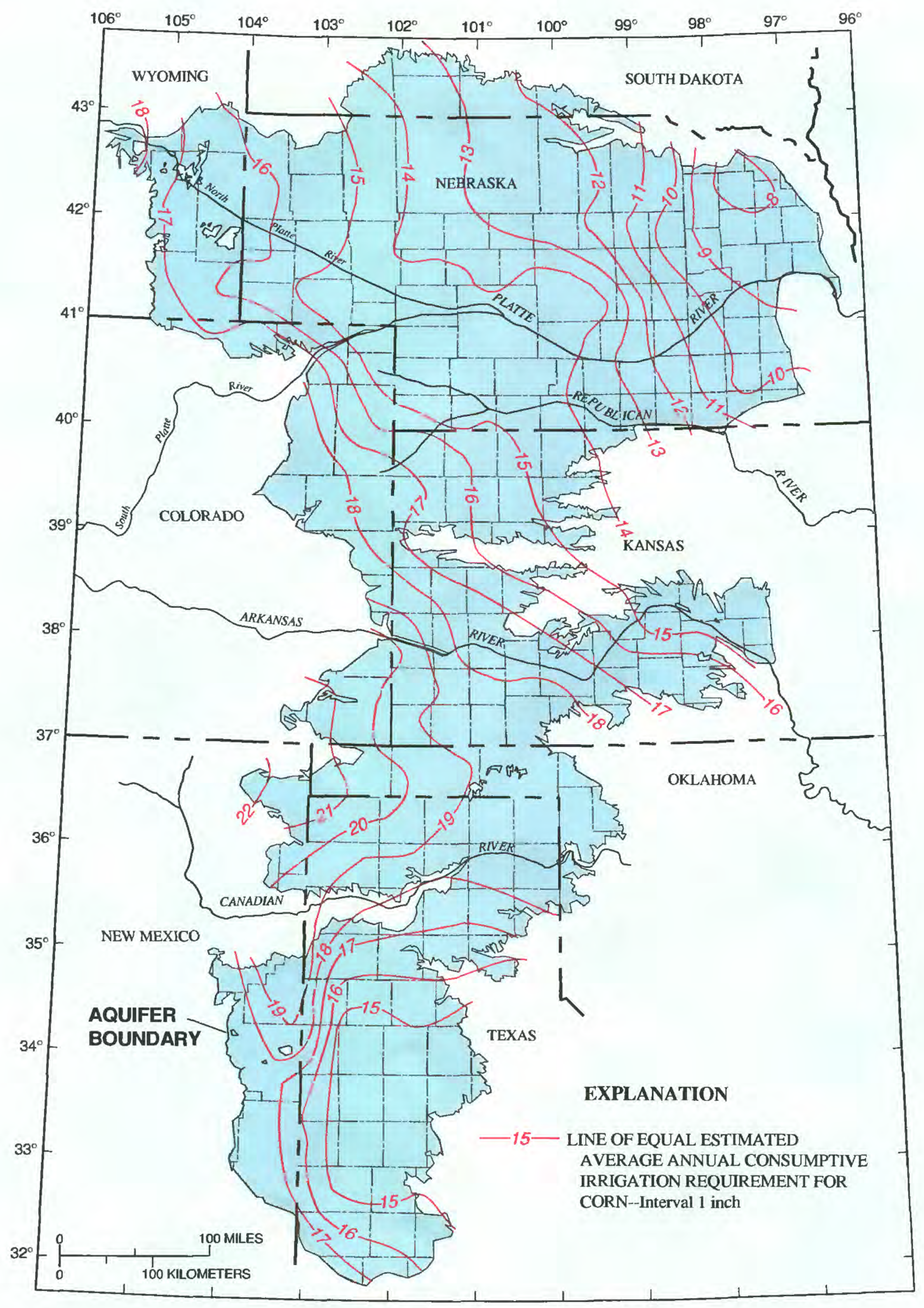

Figure 5. Estimated average annual consumptive irrigation requirement for corn, 1951-80 (modified from Dugan and Zelt, in press). 


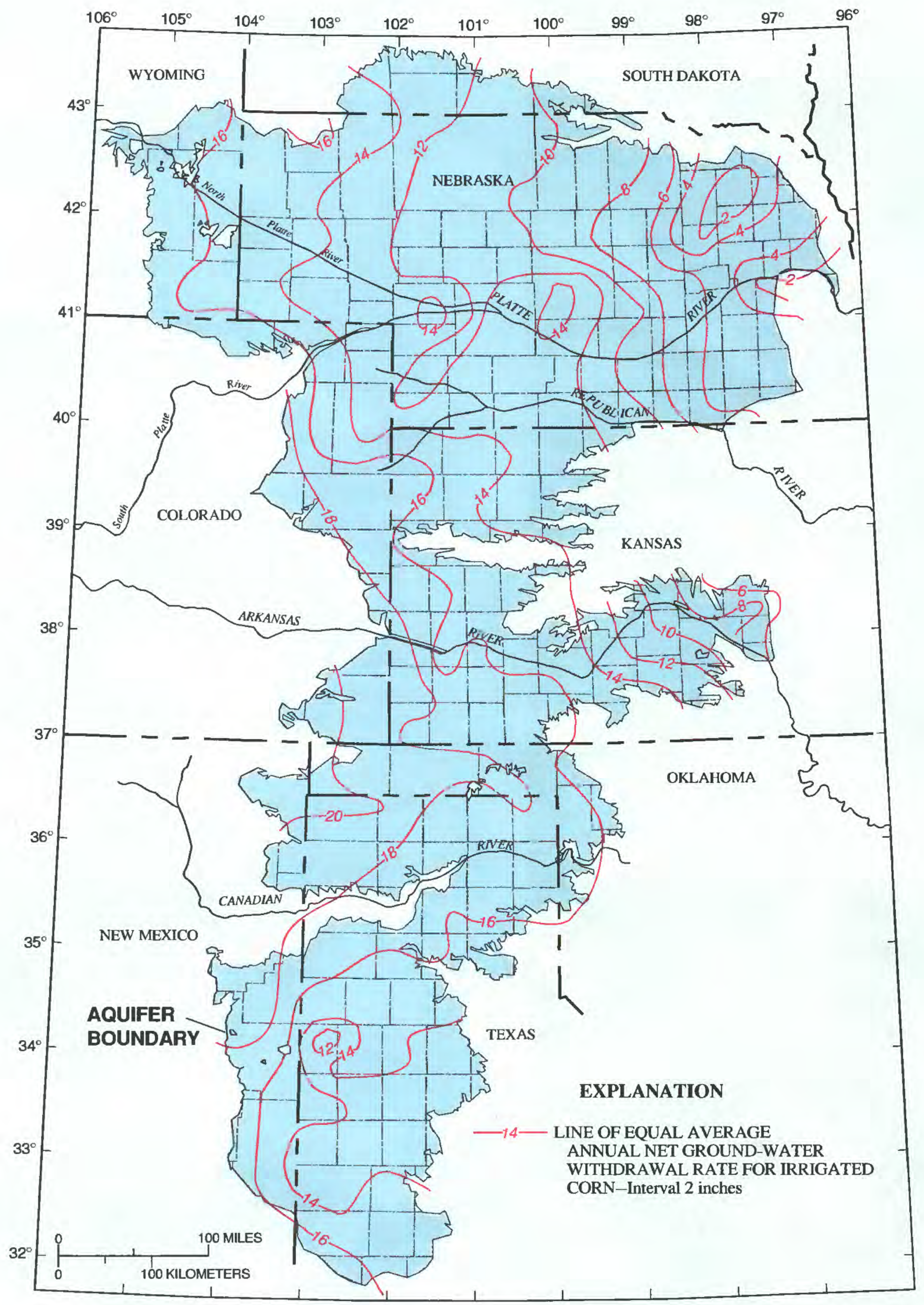

Figure 6. Estimated average annual net ground-water withdrawal rate for irrigated corn, 1951-80 (modified from Dugan and Zelt, in press). 


$$
\mathrm{W}_{\mathrm{n}}=\mathrm{C}_{\mathrm{i}}-\mathbf{R} \text {, }
$$

where $C_{i}=$ consumptive irrigation requirement.

Consumptive irrigation requirement $\left(C_{i}\right)$ is an approximation of $\mathrm{I}_{\mathrm{p}}-\mathrm{S}_{\mathrm{i}}$ because the consumptive irrigation requirement is the minimum irrigation required to maintain adequate soil water for optimum plant growth and excess irrigation pumpage would return to the aquifer as seepage $\left(\mathrm{S}_{\mathrm{i}}\right)$, assuming runoff is negligible.

Net withdrawal rates in figure 6 are based on equation 3 and represent the combining of recharge in figure 3 and the consumptive irrigation requirement (corn) in figure 5. Although only the consumptive irrigation requirement for corn was available for these calculations, it does provide a uniform comparison of regional differences in net demand on available ground-water resources.

Estimated average annual net withdrawal rates during 1951-80 ranged from about 2 inches (acre inches per acre) in parts of northeastern Nebraska to 20 inches in parts of the Oklahoma and Texas Panhandles, southeastern Colorado, and northeastern New Mexico. In the areas of substantial ground-water withdrawals (fig. 4), net withdrawals for corn ranged from 6 to 12 inches in central Nebraska, 16 to 18 inches in southwestern Kansas, and from 12 to 20 inches in the intensively irrigated parts of the Texas Panhandle.

\section{GROUND-WATER DEVELOPMENT AND WATER-LEVEL CHANGES, PREDEVELOPMENT TO 1980}

The availability and development of water resources have major roles in the development of the High Plains as an agricultural region. The perceived limitations of the natural environment of the High Plains, particularly the climate, made the availability of water even more important. Water, however, was not the only limiting factor in the development of the High Plains.

Permanent settlement of the High Plains did not begin until late in the 19th century. Most early assessments considered the region unsuited for permanent agriculture and only marginally suited for a grazing economy. Journals from a U.S. Army expedition led by Major Stephen Long that crossed the High Plains in 1819-20 described the region as an "...extensive section of the country...almost wholly unfit for cultivation, and of course uninhabitable by a people depending upon agriculture for their subsistence..." (Dick, 1975, p. 2). These and other negative perceptions of the plains lingered until after the Civil War (1861-65) and inhibited widespread interest in settling the region.

Many of the long-standing perceptions of the High Plains were based on substantiated observations. Frequent drought, insect infestations, prairie fires, sparsity of surface water, and scarcity of wood for building and fuel certainly were apparent in the High Plains. In addition, the large farming operations required for the given climatic limitations of the region had to await certain technological innovations in the middle of the 19th century, which included the steel plow to break the tough grassland sod and the mechanical reaper to harvest large acreages. Perhaps even more significant for commercial agriculture to succeed in the High Plains was a transportation system permitting access to markets, which had to await the coming of the railroad following the Civil War.

The settlement process in the High Plains proceeded rapidly as the various obstacles to development were overcome. Settlement was encouraged through such incentives as the various government land programs, including the Homestead Act of 1862 and the Railroad Land Grants following the Civil War. Also, the railroads used extensive advertising that extolled the virtues and attempted to dispel the negative perceptions of the High Plains to recruit a large number of immigrants from Europe in order to dispose of the railroads' vast land holdings and create a market for their rail services.

Inadequate precipitation for many crops and frequent droughts soon made it apparent that nonirrigated agriculture would be difficult in the High Plains. Soon after the initial settlement phase, irrigation development began along some streams, such as the Platte and Arkansas Rivers, which permitted more intensive forms of agriculture and reliable crop production. However, surface-water irrigation was limited largely to major stream valleys. Widespread irrigation of the High Plains awaited the development of ground water.

Dryland farming techniques and crop experimentation met with only limited success in the late 
19 th and early 20 th centuries, yet there was a spirit of optimism that a permanent improvement in climate would occur. The persistent drought of the 1930's brought true arid conditions that permanently altered perceptions about the plains and provided the first major impetus for widespread development of irrigation. The series of near-total crop failures coupled with the low commodity prices during the Great Depression (1929-39) indicated a need to minimize the agricultural risk factors in the High Plains. Irrigation was perceived as the solution to the large fluctuations in agricultural production and frequent catastrophic crop failures. Thus, the agricultural economy of the High Plains could be stabilized through irrigation.

After World War II (1939-45), various factors served as further stimulants to irrigation development throughout the High Plains. High commodity prices and decreasing costs for irrigation associated with technological advances made irrigation economically feasible. Prolonged, widespread drought and resultant crop failures during the 1950's reinforced the concept that irrigation was needed to minimize agricultural risk.

Significant development of ground water for irrigation in the High Plains depended upon such technological developments in the early and mid20th century as gasoline and diesel engines, rotary drills, and turbine pumps. Early irrigation wells were shallow, commonly hand dug, and largely restricted to shallow water-table areas in large stream valleys. Irrigation in the uplands, where the water table generally was at considerable depth depended on later development of efficient, lowcost drilling and pumping techniques.

Cost-efficient pumping from depths greater than 100 feet was not available until the early 1960's with the advent of more efficient powerplants to run turbine pumps (Weeks and others, 1988, p. A10).

An even more significant technological advancement that became widely adopted in the 1960 's was the center-pivot irrigation system, a self-propelled sprinkler irrigation system that made it possible to irrigate areas where topography or soils were unsuited for gravity or flood irrigation methods. Millions of acres of sandy soils and rolling topography formerly unsuitable for irrigation became potentially irrigable.
Energy resources were perhaps as important as technology for the development of ground-water irrigation in the High Plains. The long period of ground-water irrigation expansion from World War II into the 1970's was attributable in large part to inexpensive energy. Rural electrification and development of natural gas fields and pipelines in the High Plains during the 1940's and 1950's provided low-cost energy for pumping. Where these energy sources were not available, low-cost diesel fuel was the principal alternative energy source. However, since the increase in petroleum prices in 1974, the cost of energy has been a factor in controlling expansion, particularly in areas where the aquifer limits irrigation well yields or where irrigation lift costs are relatively large.

The process of irrigation development and associated water-level changes in the uplands of the High Plains generally proceeded from south to north. Numerous factors, including ease of developing water resources, availability of readily irrigable land, pre-existing cropping systems, and perceived economic benefits affected the patterns of irrigation development.

Documented water-level changes generally began to occur soon after irrigation began in the various parts of the High Plains. Water-level declines were apparent in the Southern High Plains by 1940 , the Central High Plains by 1950 , and the Northern High Plains by 1960 . There were notable exceptions to this pattern of development, such as in Box Butte County in the Nebraska Panhandle, where ground-water development followed by water-level declines began in the early 1950's. Water-level rises began in the uplands of southcentral and southwestern Nebraska in the early 1940's as a result of seepage from Platte River surface-water diversions for irrigation and power generation. Some areas of the High Plains, including north-central Nebraska, South Dakota, and parts of Colorado and Wyoming are not suitable for extensive irrigation development principally because of soil, topographic, or hydrologic limitations; therefore, water levels have remained essentially stable in these areas.

The water-level changes from initial development or predevelopment to 1980 are shown in figure 7. Predevelopment water levels, as used here, are the estimated water levels that existed prior to any effects imposed by human activity. A 


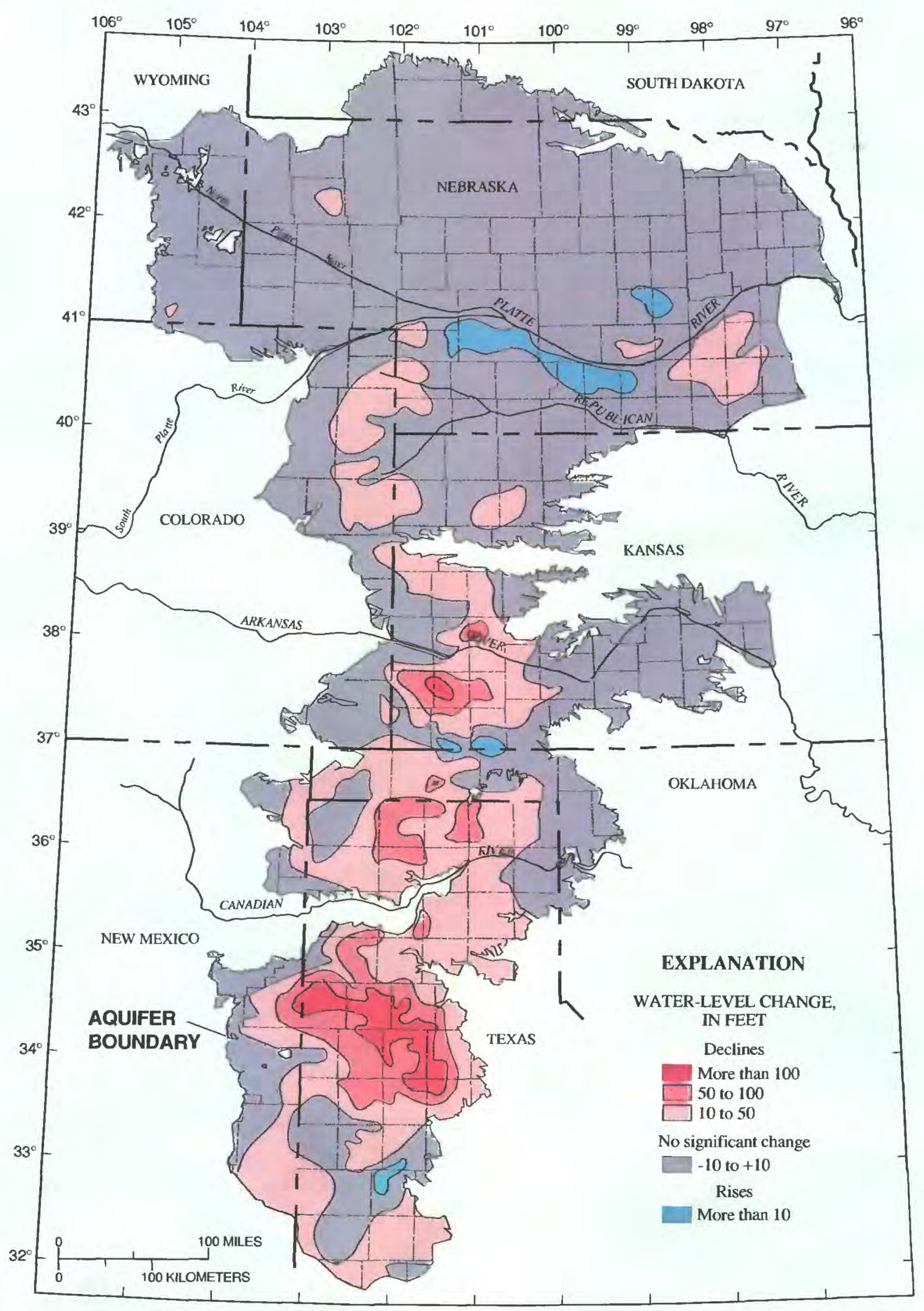

Figure 7. Water-level change in the High Plains aquifer, predevelopment to 1980 (modified from Luckey and others, 1981). 


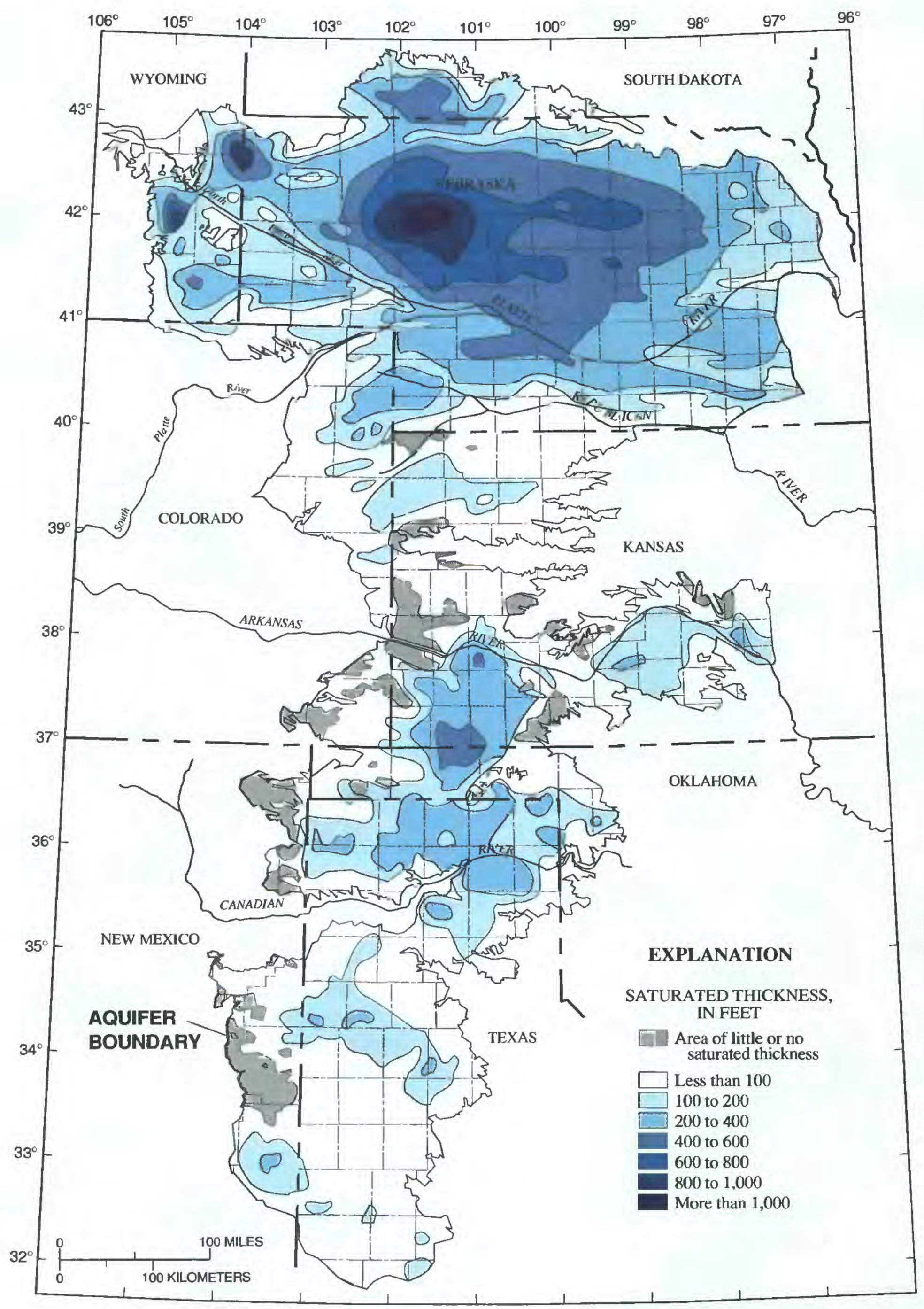

Figure 8. Saturated thickness of the High Plains aquifer, 1980 (modified from Weeks and Gutentag, 1981; Gutentag and others, 1984). 
predevelopment water level generally represents seasonally high water-table conditions, usually occurring in early spring.

By 1980, the largest decline in water levels had occurred in the Southern High Plains of Texas and New Mexico (fig. 7). Water levels declined more than 50 feet in a large part of this area, with a maximum decline of nearly 200 feet occurring in Texas. Declines exceeding 50 feet occurred in several smaller areas of the Central High Plains of southwestern Kansas, the north-central Panhandle of Texas, and the central Panhandle of Oklahoma. Maximum declines in the Central High Plains exceeded 100 feet in two small areas of southwestern Kansas. Only small areas of 10- to 50-foot declines occurred in the Northern High Plains by 1980. In addition to the area of water-level rise associated with surface-water diversions in southcentral and southwestern Nebraska, smaller areas of rise occurred in central Nebraska, along the Kansas-Oklahoma border, and the extreme Southern High Plains of Texas. The rise in central Nebraska also is associated with surface-water diversions (Luckey and others, 1981).

The regional differences in magnitude and areal extent of water-level declines from predevelopment to 1980 (fig. 7) are partly time dependent. The absence of areas of decline exceeding 50 feet in the Northern High Plains is attributable partly to the later development of irrigation in that area.

The saturated thickness of the High Plains aquifer in 1980 ranged from less than 100 feet in much of the High Plains to more than 1,000 feet in parts of north-central Nebraska and southeastern Wyoming (fig. 8). The saturated thickness averaged about 340 feet in Nebraska (table 1), but the saturated thickness of the aquifer averaged only about 110 feet in the remainder of the High Plains (Gutentag and others, 1984). The saturated thickness was less than 100 feet in 46 percent of the High Plains area and exceeded 600 feet in only 5 percent of the area (Gutentag and others, 1984, p. 23-24). Saturated thickness in the major irrigated areas of Kansas, Nebraska, and the northern Panhandle of Texas generally was 200 to 400 feet and 100 to 200 feet in the Southern High Plains of Texas. By 1980 saturated thickness had decreased substantially in parts of Kansas and Texas since predevelopment as a result of declining water levels prior to 1980 (fig. 7).
Large but discontinuous parts of the High Plains aquifer in the Central High Plains had little or no saturated thickness in 1980 (fig. 8). The largest of these areas were in west-central Kansas, northeastern New Mexico, and southeastern Colorado. In the Southern High Plains, a large part of the aquifer in east-central New Mexico had little or no saturated thickness. In the Northern High Plains only two small areas in northwest and west-central Kansas had little or no saturated thickness.

Areas that had little or no saturated thickness in 1980 generally are along the boundaries of the High Plains or where deposits of late Tertiary and Quaternary age largely have been removed by erosion. The extent of the areas of little or no saturated thickness in 1980 probably is comparable to predevelopment conditions because these areas could not have sustained any substantial groundwater development. Adequate supplies of ground water even for livestock and rural domestic purposes generally are not available in these areas. Observation wells, if present in these areas, probably do not represent water-level conditions in the High Plains aquifer. Subsequent discussions of water-level changes in the High Plains aquifer do not consider these areas that had little or no saturated thickness in 1980.

An estimate of the volume of ground water in storage in the High Plains aquifer can be calculated from average saturated thickness and aquifer specific yield. The area-weighted average saturated thickness of the High Plains aquifer (table 1) was about 190 feet in 1980 (Gutentag and others, 1984). The specific yield (the volume of water that will drain by gravity from aquifer pore spaces) averages about 15 percent $(0.15)$ of the total volume of saturated material (Gutentag and others, 1984). Therefore, the estimated total volume of water that could drain from the aquifer in 1980 was about 3,250 million acre-feet (table 1). Pumping costs in relation to well yields, however, would limit the availability of much of this water.

\section{GROUND-WATER-LEVEL OBSERVATION-WELL NETWORK}

Monitoring of water-level changes in the High Plains aquifer is accomplished using an extensive 
observation-well network (figs. 9 and 10). Waterlevel changes between 1980 and 1992 were based on measurement of water levels in nearly

6,600 wells. Observation wells added since 1980 increased the number of observations used to compute changes between 1991 and 1992 to nearly 8,200 (table 4). Although the difference in number of observations between 1980 to 1992 and 1991 to 1992 limits exact comparisons of water-level changes between the two time periods, these differences are not large enough to prevent reasonable comparisons because the vast majority of 1980,1991 , and 1992 water-level measurements were made in the same wells. The additional observation wells used in 1991 and 1992 tend to be located in areas where additional ground-water development for irrigation has occurred since 1980.

The observation-well network used for monitoring water-level change between 1980 and 1992 and between 1991 and 1992 has expanded since the initial report in this series (Kastner and others, 1989). In that report, the network for the $1980-88$ changes consisted of 4,719 wells and for the 1987-88 changes consisted of 6,203 wells. Most of the network expansion resulted from acquisition of additional observation-well data from local sources in Texas.

The number of observation wells in the network varies from year to year. Some observation wells have been permanently lost from the network, particularly those providing long-term observations (1980 or earlier). These are typically older wells that often are no longer measurable because of structural failure, plugging, or insufficient depth to penetrate a declining water table. Short-term loss of observations from the network may result because the measuring period coincides with recent pumping of the observation well or nearby wells and water levels have not fully recovered. These yearly variations in the data base are usually small and widely scattered spatially and do not have a significant effect on water-level-change patterns.

The variable density and location of observation wells within the network (figs. 9 and 10) are governed principally by the intensity of groundwater irrigation development. Areas with larger percentages of irrigated land tend to contain a greater density of observation wells. In contrast, those areas with little or no irrigation development tend to have lesser densities of observation wells. In many areas, particularly where the aquifer has little or no saturated thickness, few measurable wells are available.

Most of the observation wells in the network are privately owned irrigation wells with access ports and sufficient diameters to permit ready access with a measuring device. Irrigation wells are especially well suited for monitoring watertable changes because their large diameter and large pumping capacity make them less prone to plugging, which is common in small-diameter, small-capacity wells. A small percentage of the observation wells are designed specifically for water-level monitoring, and some are equipped with recording devices for continuous monitoring of water levels. Few wells designed for municipal, domestic, or livestock uses are suitable for water-level monitoring.

Water levels are measured by personnel of numerous Federal, State, and local agencies in the High Plains. Local water and natural resource conservation districts are responsible for the largest number of these water-level measurements. The USGS is responsible for compiling the water-level data and maintaining the water-level data bases in most States.

Measurements usually are made in the winter and early spring when water levels generally have fully recovered from pumping during the previous irrigation season and represent the highest watertable conditions during the year. Irrigation of winter wheat in the western High Plains in the late winter and early spring occasionally requires selection of alternative measurement periods in those areas. In some areas, particularly in the Northern High Plains, measurements are made only in the fall following the irrigation season because winter and spring weather typically is not conducive to field work. Consistency from year to year in date of measurement is more critical than the measurement season because consistency maintains a more reliable comparability among annual water levels. 


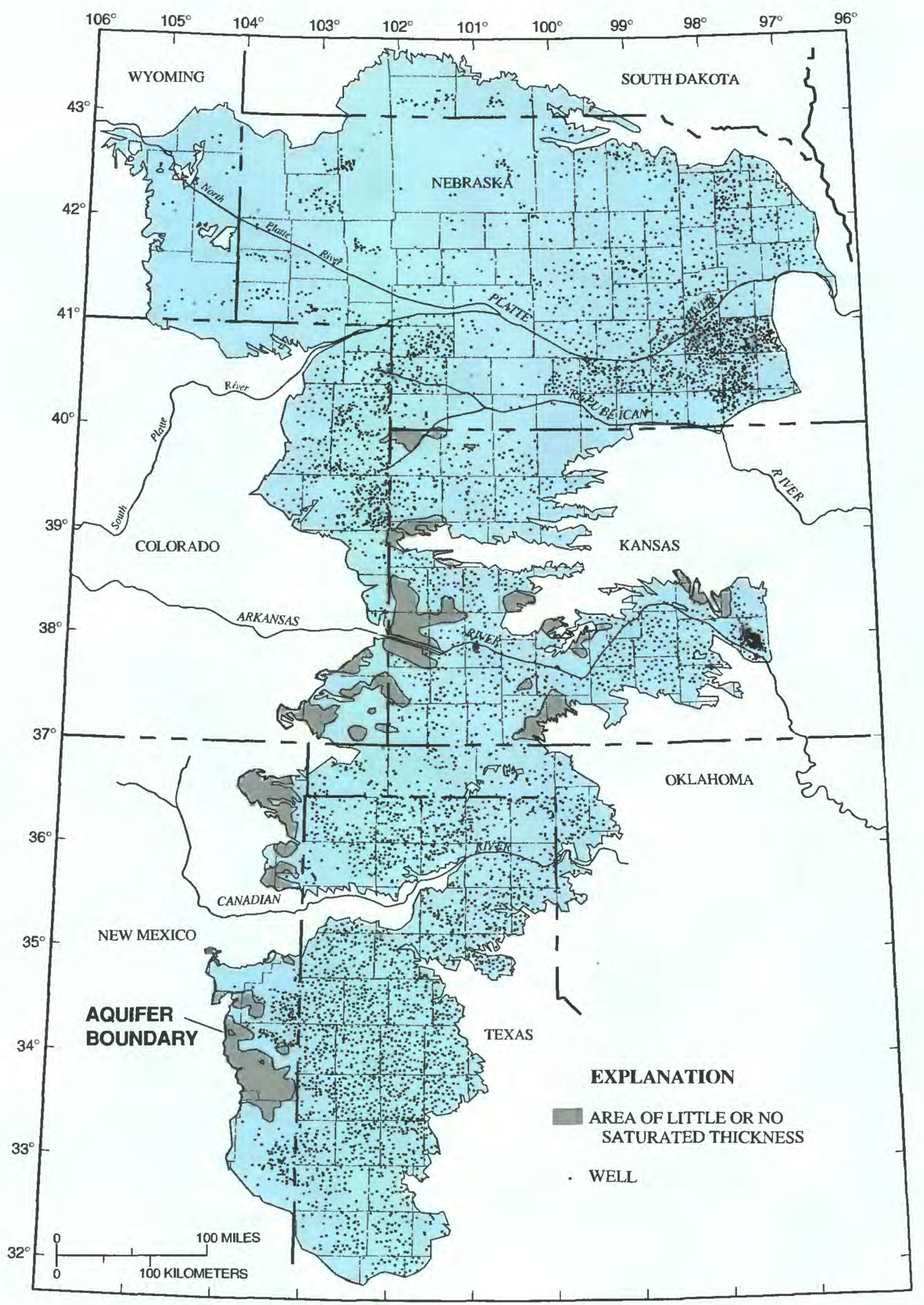

Figure 9. Location of observation wells with water-level measurements in 1980 and 1992. 


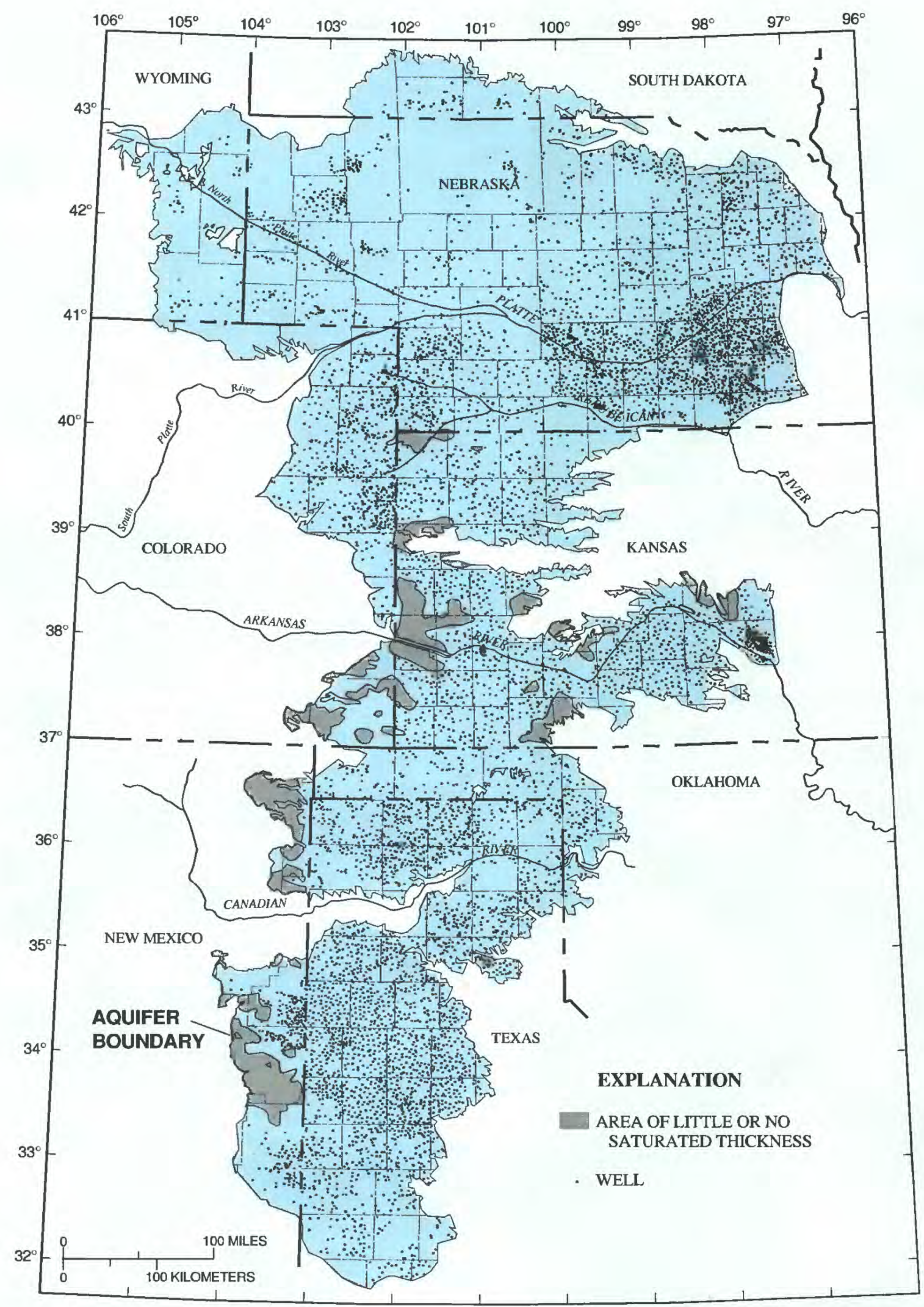

Figure 10. Location of observation wells with water-level measurements in 1991 and 1992. 
Table 4. Number of observation wells measured in 1980 and 1992 and in 1991 and 1992

\begin{tabular}{lrr}
\hline & \multicolumn{2}{c}{$\begin{array}{c}\text { Number of observation wells } \\
\text { measured }\end{array}$} \\
\cline { 2 - 3 } \multicolumn{1}{c}{ State } & $\mathbf{1 9 8 0}$ and 1992 & $\mathbf{1 9 9 1}$ and 1992 \\
\hline Colorado & 560 & 599 \\
Kansas & 1,077 & 1,386 \\
Nebraska & 2,167 & 3,097 \\
New Mexico & 215 & 260 \\
Oklahoma & 226 & 246 \\
South Dakota & 38 & 58 \\
Texas & 2,288 & 2,493 \\
Wyoming & 24 & 51 \\
& & \\
Total & 6,595 & 8,190 \\
\hline
\end{tabular}

\section{METHODS OF DATA ANALYSIS AND PRESENTATION}

Areas of equal water-level-change and precipitation deviations from normal are defined through the use of Thiessen polygons (Thiessen, 1911). In this method, the area of interest is divided into polygons, each containing one water-level or precipitation measurement site. The sizes and shapes of polygons are governed by the geographic distributions of measurement sites. Where sites are widely spaced, the polygons are large; conversely, where sites are closely spaced, the polygons are small. Although other methods can be used to depict areas of equal water-level change or precipitation deviations, Thiessen polygons were deemed the most suitable for the small-scale maps used in this report. The use of the polygon method, however, can result in abrupt differences among values of adjacent polygons, whereas actual waterlevel-change or precipitation deviation between wells or sites may be gradational.

The patterns of water-level change in the High Plains contain numerous apparent anomalies. A water-level change at a well can represent unique local conditions because of a number of factors, including well construction, local geohydrology, intensity of irrigation in the immediately surrounding area, local soil and vegetation characteristics, and localized precipitation anomalies. Thus, in the subsequent interpretation of the water-level-change maps, the anomalies likely are a result of unique conditions rather than data uncertainties.

Area-weighted averages for water-level change, precipitation deviations, and change in saturated thickness, presented later in tables 5-10, are deemed more appropriate than the arithmetic average of the observed point data. The nonuniform distribution of observation points would result in an arithmetic average that would tend to be over-represented by small areas with a large density of observation points. An area-weighted average is created by weighting the values assigned to a Theissen polygon by the polygon's area. Thus, each unit area, rather than each observation point, receives equal statistical representation.

Water-level changes during the periods 1991 to 1992 and 1980 to 1992 are discussed in relation to annual precipitation characteristics during approximately comparative time periods (1991 and 1981 through 1991, respectively). Although many factors discussed previously affect water levels, annual precipitation in this report serves as a point of reference for analyzing possible causes of changes in water levels. It will be indicated frequently in the subsequent discussions that certain patterns of water-level change have no apparent relation to concurrent annual precipitation amounts or deviations from normal, and other factors must be considered, including the following: seasonal precipitation patterns, consumptive irrigation requirements; and local aquifer characteristics. 


\section{WATER-LEVEL CHANGE AND PRECIPITATION, 1980 to 1992}

The geographic patterns of water-level change established in the High Plains from predevelopment to 1980 (fig. 7) generally continued during the 1980-to-1992 period (fig. 11). Those areas with substantial water-level declines from 1980 to 1992 are largely the same areas with large declines prior to 1980. Cumulative declines in most areas of water-level decline in the High Plains, however, were generally much smaller after 1980 , both as a result of a shorter time period and a slower annual rate of depletion of the aquifer. Only in a few areas of large water-level declines both before and after 1980 has the apparent rate of depletion of the aquifer remained relatively constant through the two time periods.

\section{General Water-Level Changes}

Water levels in the High Plains declined an average of 2.24 feet from 1980 to 1992 , as compared to a decline of 9.9 feet from predevelopment to 1980 (table 5). The average annual rate of water-level decline from regional predevelopment (1940) to 1980 was about 0.25 foot. From 1980 to 1992 , the average annual rate of decline was about 0.19 foot or 76 percent of the pre-1980 annual rate. The pre-1980 annual rate of decline probably would have been much larger if the acreages irrigated prior to 1980 had been as large as those irrigated after 1980. In 1964, which represents the approximate mid-point of the predevelopmentto- 1980 period, about 7,000,000 acres were irrigated in the High Plains (Gutentag and others, 1984). Since 1980 , about $14,000,000$ acres have been irrigated in the High Plains (Weeks, J.B., in Sun, 1986, p. 30). Most of the growth in irrigated acreage after 1964 was in the Northern High Plains, where conditions are less conducive to large water-level declines than in the Central and Southern High Plains because of greater potential recharge, smaller consumptive irrigation requirements, and smaller net withdrawals from the aquifer (figs. 3, 5, and 6). Total irrigated acres in the Central and Southern High Plains, where the largest declines occurred prior to 1980 , actually have decreased since the late 1970's (Dugan and
Schild, 1992). More than half of the $14,000,000$ acres irrigated in the High Plains after 1980 were in the northern subdivision, particularly in Nebraska. Thus, the geographic shift of irrigation development to areas of smaller potential rates of aquifer depletion may account partly for the decreased annual rate of water-level decline since 1980.

Certain changes in irrigation practices appear to also have contributed to the slower rate of aquifer depletion after 1980. Although the individual and accumulative effects of these practices on the depletion rate of the entire High Plains aquifer are difficult to assess quantitatively, their waterconserving attributes have been widely documented:

(1) Advances in irrigation technology, including center-pivot sprinkler irrigation and lightweight gated pipe designed to apply water more evenly and minimize conveyance and field losses, have greatly decreased ground-water pumpare requirements. Irrigation from open ditches, which can result in water losses of as much as 50 percent, is no longer commonly practiced. Recent sprinkler designs, including the low-energy, preciseapplication (LEPA) method, minimize wind losses from center-pivot irrigation. Surge irrigation permits more uniform field application by the gravity method and less need to exceed crop requirements in certain parts of the field to assure complete coverage. Although much of the excess water applied by various methods in the past was returned to the underlying aquifer through percolation, substantial volumes of water were lost by runoff and evaporation of ponded water.

(2) Irrigation management practices have been widely adopted to minimize pumpage costs and conserve water. Agricultural production has been converted to crops or plant varieties with smaller consumptive irrigation requirements. Irrigation scheduling, including monitoring of soil-water conditions, is commonly practiced to minimize excess application of irrigation water.

(3) Large water-level declines in some areas of the High Plains prior to 1980 prompted local regulations to control irrigation withdrawals. State and local agencies were granted the authority to monitor and regulate pumpage volumes from existing wells, to regulate well spacing, and to limit new well construction. Irrigation runoff also has been limited in many parts of the High Plains since 


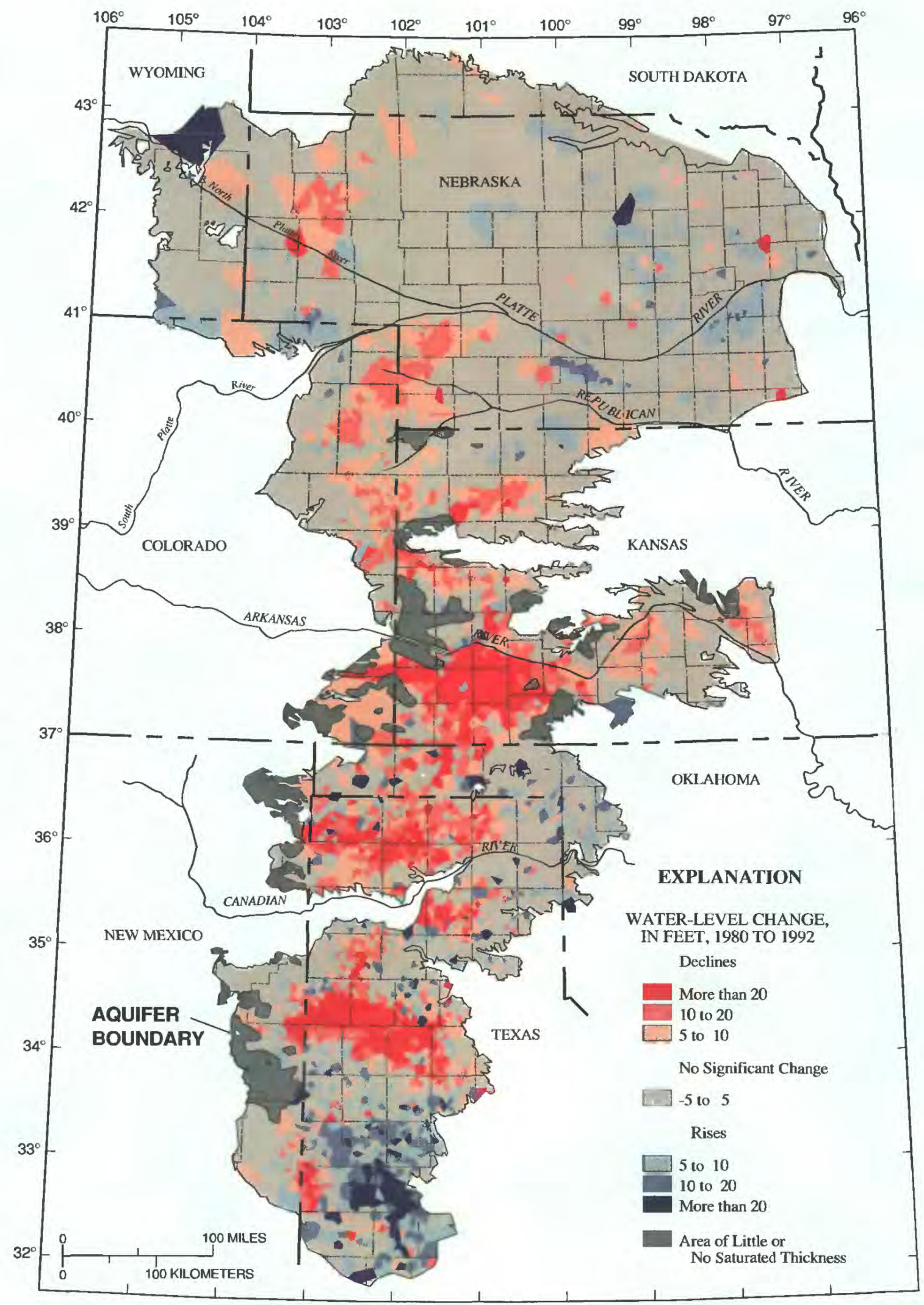

Figure 11. Water-level change in the High Plains aquifer, 1980 to 1992. 


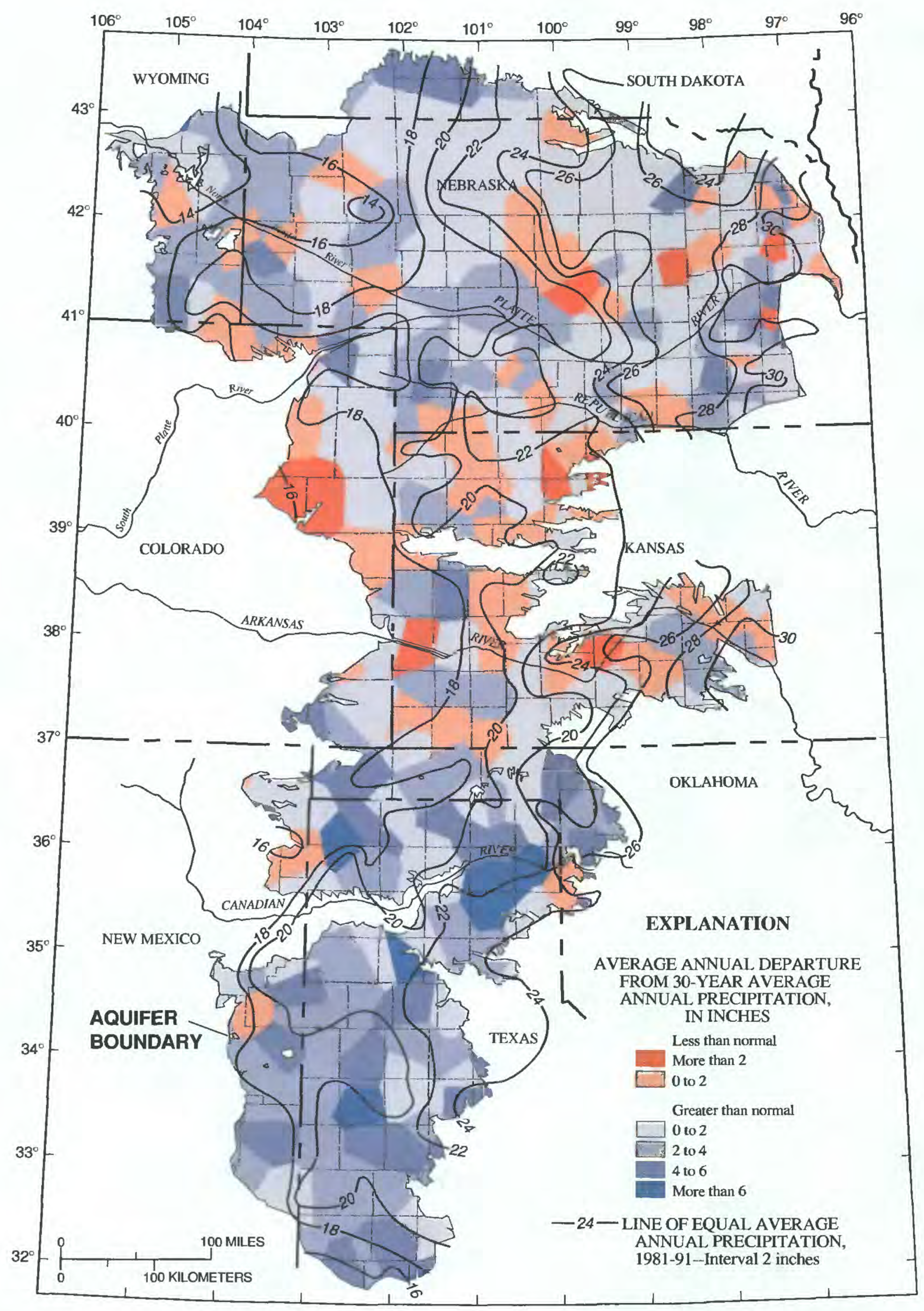

Flgure 12. Average annual precipitation, 1981-91, and average annual departure from 30-year normal (1951-80) (precipitation data from National Climatic Data Center, 1951-91). 
Table 5. Average area-weighted water-level changes and estimated changes in volume of water in storage, predevelopment to 1980 and from 1980 to 1992

\begin{tabular}{|c|c|c|c|c|}
\hline \multirow[b]{2}{*}{ State } & \multicolumn{2}{|c|}{ Area-weighted water-level change (feet) } & \multicolumn{2}{|c|}{$\begin{array}{l}\text { Estimated changes in volume of water in } \\
\text { storage (millions of acre-feet) }\end{array}$} \\
\hline & $\begin{array}{l}\text { Predevelopment to } \\
1_{1980}\end{array}$ & 1980 to 1992 & $\begin{array}{l}\text { Predevelopment } \\
\text { to }{ }^{1} 1980\end{array}$ & 1980 to 1992 \\
\hline Colorado & -4.2 & -3.04 & -6.0 & -4.3 \\
\hline Kansas & -9.9 & -7.39 & -29.0 & -21.7 \\
\hline Nebraska & 0 & -.27 & 0 & -1.6 \\
\hline New Mexico & -9.8 & -1.86 & -9.0 & -1.7 \\
\hline Oklahoma & -11.3 & -1.80 & -8.0 & -1.6 \\
\hline South Dakota & 0 & +.08 & 0 & +.03 \\
\hline Texas & -33.7 & -2.46 & -114.0 & -8.3 \\
\hline Wyoming & 0 & +1.30 & 0 & +1.0 \\
\hline High Plains & -9.9 & -2.24 & -166.0 & -38.2 \\
\hline
\end{tabular}

${ }^{1}$ From Gutentag and others (1984, p. 47).

the late 1970's by regulations requiring such practices as reuse pits.

During the early and mid-1980's, certain climatic and economic conditions were favorable for the recovery or stabilization of water levels in the High Plains. Water levels in the High Plains aquifer actually rose, averaging about +0.01 foot per year from 1980 to 1988 (Kastner and others, 1989). Subsequently, the average water level declined at an increasing rate as shown below:

\begin{tabular}{|c|c|c|}
\hline Time period & $\begin{array}{c}\text { Average } \\
\text { water-level } \\
\text { change, in } \\
\text { feet per year }\end{array}$ & Data source \\
\hline 1980 to 1988 & +0.01 & Kastner and others, 1989 \\
\hline 1980 to 1989 & -.03 & Dugan and others, 1990 \\
\hline 1980 to 1990 & -.10 & Dugan and Schild, 1992 \\
\hline 1980 to 1991 & -.13 & $\begin{array}{l}\text { McGrath and Dugan, } \\
1993\end{array}$ \\
\hline 1980 to 1992 & -.19 & This report \\
\hline
\end{tabular}

Two factors, precipitation and government agricultural policies, appear to have contributed to rises in some areas and slower rates of decline in most other areas in the early and mid-1980's. Annual precipitation in the High Plains during 1981-87 averaged 2.94 inches above normal. Throughout much of the eastern half of the High Plains in Nebraska and the southern part of the
Southern High Plains, where there were substantial areas of water-level rise from 1980 to 1988 , precipitation averaged more than 6 inches above normal during 1981-87 (Kastner and others, 1989). The early 1980's saw the initiation of short-term Federal Government agricultural programs, including Payment in Kind (PIK), that encouraged the setting aside of large acreages of irrigated cropland to decrease crop reserves and to increase commodity prices (Kastner and others, 1989).

The two factors associated with the slower annual rate of water-level decline from 1981 to 1987 were not present from 1988 to 1992 when the annual rate of water-level decline steadily increased: (1) Precipitation returned to near normal during 1988-91 (+0.02 inch). (2) Large acreages of irrigated cropland set aside as a result of short-term government programs in the early 1980 's returned to production after the mid-1980's.

\section{Regional Water-Level Changes}

An examination of the regional patterns of water-level change from 1980 to 1992 (fig. 11) indicate large regional contrasts. These regional differences result from both short- and long-term regional variability of the following factors that affect water-level change: (1) Although precipitation in most parts of the High Plains was above 
normal during 1981-91 (fig. 12, table 6), some areas were considerably above normal, whereas other areas were near to slightly below normal. (2) Long-term regional differences in recharge (fig. 3) and consumptive irrigation requirements (fig. 5) result in large differences in net withdrawals from the aquifer (fig. 6). (3) Considerable regional and local differences exist in the intensity of irrigation development and ground-water withdrawal rates (fig. 4). (4) Regional and local differences in the hydrogeology of the High Plains aquifer result in differences in the aquifer's hydraulic characteristics and the response to ground-water development.

\section{Northern High Plains}

The total area of water-level declines exceeding 5 feet from 1980 to 1992 in the Northern High Plains was relatively smaller than comparable declines in the other subdivisions of the High Plains (fig. 11). The largest area with declines exceeding 5 feet was a relatively continuous area including parts of southwestern Nebraska, northeastern Colorado, and northwestern Kansas. Substantial irrigation development began in this area in the early to mid-1960's, and by 1980 water levels had declined between 10 and 50 feet throughout much of the area (fig. 7). From local predevelopment in this area (1965) to 1980, the average rate of water-level decline was about 2 feet per year. From 1980 to 1992, water levels declined about 1 foot per year. In parts of Sheridan and Thomas Counties, Kansas, where water-level declines exceeded 20 feet from 1980 to 1992, the rate of decline since 1980 has been about 1.5 to 2.0 feet per year.

The potential for water-level declines in southwestern Nebraska, northeastern Colorado, and northwestern Kansas is relatively large because of the intensive irrigation development indicated by the ground-water withdrawal rates (fig. 4), small recharge rates (fig. 3), and large consumptive irrigation requirements (fig. 5). Ground-water regulations that limit new well construction and ground-water withdrawals were imposed in the late 1970's in Chase, Dundy, and Perkins Counties, Nebraska, and in parts of the Northern High Plains of Colorado and Kansas. These regulations may have contributed to slower rates of decline from 1980 to 1992 as compared to 1965-80. Precipitation during 1981-91 was generally above normal throughout most of this area, except in parts of northwestern Kansas and extreme southwestern Nebraska (fig. 12). The below-normal precipitation in northwestern Kansas may have contributed to water-level declines exceeding 20 feet in parts of Sheridan and Thomas Counties.

Another area of large water-level declines (10 to 20 feet) in the Northern High Plains from 1980 to 1992 is in Box Butte and northern Morrill Counties in the Panhandle of Nebraska. Irrigation development began in this area in the early 1950's and was followed by declines averaging about 30 feet by 1980 in parts of Box Butte County (fig. 7) or about 1 foot per year. From 1980 to 1992 declines averaging about 15 feet or about 1.25 feet per year occurred in a substantially larger area. This is an area of small recharge rates (fig. 3), large consumptive irrigation requirements (fig. 5), and large ground-water withdrawals (fig. 4). Precipitation was slightly above normal in this area during 1981-91, averaging about 14 inches annually.

Water levels rose in several parts of the Northern High Plains from 1980 to 1992, generally in areas of above-normal precipitation during 1981-91. Discontinuous areas with rises of 5 to 10 feet occurred in the eastern High Plains of Nebraska, where precipitation was commonly 2 to 4 inches above normal. The magnitude and area of the 1980-to-1992 rises in eastern Nebraska, however, are substantially smaller than the 1980-to1988 rises reported by Kastner and others (1989) as a result of several years of water-level decline after 1988 (Dugan and others, 1990; Dugan and Schild, 1992).

Another area of water-level rises, as much as 10 to 20 feet since 1980 , was in south-central Nebraska. These rises resulted from seepage losses from surface-water irrigation. Water-level rises have exceeded 50 feet throughout large areas of Gosper, Phelps, and Kearney Counties in southcentral Nebraska since predevelopment (1940) (Ellis and others, 1990). This has caused substantial areas of cropland to become saturated and lost from production. The trend of rising water levels has been reversed since the late 1980's through remedial pumping in high water-table areas and by lining canals to reduce seepage losses. 
Table 6. Area-weighted average annual precipitation during 1981-91 and departure from 30-year normal precipitation (1951-80)

[data from U.S. Department of Commerce, National Climatic Data Center, Asheville, North Carolina]

\begin{tabular}{lcc}
\hline \multicolumn{1}{c}{ State } & $\begin{array}{c}\text { Area-weighted average annual } \\
\text { precipitation (inches) }\end{array}$ & $\begin{array}{c}\text { Area-weighted average } \\
\text { departure (inches) }\end{array}$ \\
\hline Colorado & 17.37 & +1.35 \\
Kansas & 21.64 & +1.02 \\
Nebraska & 22.18 & +1.34 \\
New Mexico & 18.41 & +3.56 \\
Oklahoma & 21.30 & +2.79 \\
South Dakota & 19.82 & +1.43 \\
Texas & 20.61 & +2.75 \\
Wyoming & 15.61 & +1.78 \\
& & \\
High Plains & 20.76 & +1.74 \\
\hline
\end{tabular}

Widely scattered areas of water-level rise also occurred in Wyoming, extreme northeastern Colorado, and the southern Nebraska Panhandle from 1980 to 1992 . These rises generally were in areas where precipitation was well-above normal during 1981-91 (figs. 11 and 12).

\section{Central High Plains}

Water-level declines from 1980 to 1992 exceeding 5 feet extended throughout large parts of the Central High Plains (fig. 11). These declines exceeded 20 feet in a large, nearly continuous area of southwestern Kansas, the central Panhandle of Oklahoma, and the northern Panhandle of Texas. Water levels declined as much as 50 to 100 feet in parts of this area from local predevelopment (1950) to 1980 , and the declines exceeded 100 feet in some small areas of southwestern Kansas and the Oklahoma Panhandle (fig. 7). The average annual rate of decline in this area from predevelopment to 1980 was about 2.5 feet. The rate of decline was about 2 feet per year from 1980 to 1992; but the area of decline is considerably larger than the area of decline from predevelopment to 1980 .

Irrigation development continued in parts of southwestern Kansas until about 1983, which could account for the enlarged area of declines from 1980 to 1992 (Kastner and others, 1989).
Average annual precipitation during 1981-91 (fig. 12), which ranged from slightly below normal in parts of southwestern Kansas to well-above normal in the Oklahoma and Texas Panhandles, does not provide an explanation for the large water-level declines in this area from 1980 to 1992 (fig. 11). This area, however, has among the largest net withdrawal rates in the High Plains (fig. 6) as a result of small potential recharge rates (fig. 3 ) and large consumptive irrigation requirement rates (fig. 5). In addition, the intensive development of irrigated agriculture in much of this area contributes to large ground-water withdrawals (fig. 4).

Other large areas in the Central High Plains with declines exceeding 5 feet since 1980 are southeastern Colorado, south-central Kansas, and the central Panhandle of Texas (Carson and eastern Potter Counties). From predevelopment to 1980 , substantial water-level changes did not occur in either southeastern Colorado or south-central Kansas (fig. 7). Water levels declined as much as 50 to 100 feet, however, in the central Panhandle of Texas prior to 1980 , and additional declines since 1980 totaled more than 20 feet. The areas of decline in south-central Kansas appear to be associated with areas of below-normal precipitation during 1981-91. Precipitation, however, was 
above normal in southeastern Colorado and the central Panhandle of Texas.

Water-level rises of more than 5 feet in the Central High Plains were only in localized areas of the northern Panhandle of Texas and western Oklahoma, where ground-water withdrawal rates are generally small (fig. 4). Average annual precipitation during 1981-91 was more than 6 inches above normal throughout much of this area.

\section{Southern High Plains}

Two contrasting water-level-change trends were evident in the Southern High Plains from 1980 to 1992 and are continuations of water-level changes that occurred from predevelopment to 1980. In the northern part of the Southern High Plains, where water levels in some areas declined more than 100 feet throughout large areas prior to 1980 (fig. 7), further declines exceeding 20 feet occurred from 1980 to 1992 in a nearly continuous area extending from the New Mexico-Texas border to Floyd County, Texas (fig. 11). From predevelopment (1940) to 1980, the average annual rate of decline exceeded 2.5 feet. From 1980 to 1992, the average annual rate of decline decreased to about 2 feet. Improved irrigation management practices, decreases in irrigated acres, and precipitation averaging as much as 4 to 6 inches above normal annually during 1981-91 probably account for this slower rate of decline since 1980 (J.B. Ashworth in Dugan and Schild, 1992).

A smaller area of substantial water-level declines from 1980 to 1992 in the Southern High Plains is located in Gaines County, Texas, and Lea County, New Mexico. From predevelopment to 1980, declines were between 10 and 50 feet in this area and since 1980 have been more than 20 feet in parts of this area. Thus, the rate of decline from 1980 to 1992 , about 2 feet per year, exceeds the local predevelopment (about 1950)-to-1980 rate of less than 1 foot per year. Substantial irrigation development occurred in this area after the mid1960's (Gutentag and others, 1984), and precipitation during 1981-91 was only slightly above normal (fig. 12).

Water levels rose over a large area of the southern part of the Southern High Plains of Texas from 1980 to 1992 . Rises exceeded 20 feet in large parts of Dawson, eastern Gaines, and central Martin
Counties, Texas, an average rise of about 2 feet per year. From predevelopment to 1980 , water levels rose more than 10 feet in only one small area of Dawson and Lynn Counties. Much of the remaining areas with substantial rises since 1980 previously had declines of 10 to 50 feet from predevelopment to 1980 (fig. 7).

The water-level rises in the southern part of the Southern High Plains since 1980 appear to result from multiple causes: (1) Average annual precipitation in this area was generally 4 to 6 inches above normal during 1981-91 (fig. 12). (2) Ground-water withdrawals are generally small in this area (fig. 4).

(3) Acres irrigated have decreased since 1980. (4) Improved irrigation management and cultivation practices have been implemented. (5) The potentiometric surface of an aquifer underlying the High Plains aquifer has been rising (J.B. Ashworth, in Dugan and Schild, 1992, p. 47).

\section{Interregional Comparisons}

The large regional differences in the historical development and intensity of irrigation, potential recharge, and consumptive irrigation requirements have contributed to large regional differences in the status of the High Plains aquifer. This status may be expressed as either absolute or relative change in the saturated thickness of the aquifer (table 7). Relative change is indicated as a percentage of predevelopment saturated thickness.

The three States exclusively in the Northern High Plains; Nebraska, South Dakota, and Wyoming, where the area-weighted saturated thickness averages about 315 feet, have had virtually no change in average saturated thickness since predevelopment. The initially large saturated thickness, larger recharge rates (fig. 3), smaller consumptive irrigation requirements (fig. 5), and later development of ground-water irrigation have contributed to less depletion of the High Plains aquifer in the Northern High Plains than in the other parts of the High Plains.

North-central Nebraska, characterized by large areas of wetlands and streams with remarkably steady discharges, is among the areas with the most stable water levels in the Northern High Plains. The stability of water levels in this area results from large rates of recharge (fig. 3 ) and very small rates of ground-water withdrawals 
Table 7. Average area-weighted saturated thickness of the High Plains aquifer, predevelopment, 1980 , and 1992

\begin{tabular}{lccccc}
\hline & \multicolumn{5}{c}{ Average area-weighted saturated thickness } \\
\cline { 2 - 6 } \multicolumn{1}{c}{ State } & $\begin{array}{c}\text { Predevelopment } \\
\text { (feet) }\end{array}$ & $\begin{array}{c}\mathbf{1 9 8 0} \\
\text { (feet) }\end{array}$ & $\begin{array}{c}\text { 1980 as a } \\
\text { percentage of } \\
\text { predevelopment }\end{array}$ & $\begin{array}{c}\mathbf{1 9 9 2} \\
\text { (feet) }\end{array}$ & $\begin{array}{c}\text { 1992 as a } \\
\text { percentage of } \\
\text { predevelopment }\end{array}$ \\
\hline Colorado & 83.2 & 79.0 & 95 & 76.0 & 91 \\
Kansas & 110.9 & 101.0 & 91 & 93.6 & 84 \\
Nebraska & 342.0 & 342.0 & 100 & 341.7 & 100 \\
New Mexico & 60.8 & 51.0 & 84 & 49.1 & 81 \\
Oklahoma & 141.3 & 130.0 & 92 & 128.2 & 91 \\
South Dakota & 207.6 & 207.0 & 100 & 207.1 & 100 \\
Texas & 143.7 & 110.0 & 77 & 107.5 & 75 \\
Wyoming & 182.0 & 182.0 & 100 & 183.3 & 101 \\
& & & & & 94 \\
High Plains & 199.9 & 190.0 & 95 & 187.8 & 94 \\
\hline
\end{tabular}

(fig. 4). Coincidentally, the largest saturated thickness in the High Plains also occurs in north-central Nebraska (400 to more than 1,000 feet, fig. 8).

The area-weighted average saturated thickness in Colorado, Kansas, and Oklahoma, which comprise most of the Central Plains, was less than 100 feet in 1992 or about 85 percent of the predevelopment saturated thickness. Most of the decline in average saturated thickness is concentrated in southwestern Kansas and the Oklahoma Panhandle.

In New Mexico and Texas, which are largely in the Southern High Plains, the area-weighted average saturated thickness was less than 95 feet in 1992 , or less than 80 percent of the predevelopment saturated thickness. The larger decline in saturated thickness in the Southern High Plains than in other regions of the High Plains largely can be attributed to earlier ground-water development for irrigation. Much of the decline in average saturated thickness in the Southern High Plains, as in the Central High Plains, results from large water-level declines in a few large areas (figs. 7 and 11).

The statistics in table 7 have limited application in projecting possible future conditions in the High Plains aquifer. Vertical change in the water-storage capacity of the aquifer as the satura- ted thickness changes and the variability of net ground-water withdrawals make it impossible to make reliable projections from the past rate of change in saturated thickness alone.

\section{WATER-LEVEL CHANGE AND PRECIPITATION, 1991 TO 1992}

The geographic patterns and magnitude of water-level change from 1991 to 1992 (fig. 13) closely resemble annual changes from 1988 to 1991. Average water-level changes in these four consecutive years were similar even though average annual precipitation differed substantially (table 8). Water-level declines were widespread throughout the High Plains from 1991 to 1992 in spite of well-above normal precipitation in 1991 in much of the High Plains (tables 9 and 10). Kansas was the only High Plains State with below-normal precipitation in 1991, which may have contributed to an average area-weighted water-level decline exceeding 1.1 feet in the State. Water-level rises from 1991 to 1992 occurred in a few, widely scattered areas where precipitation was generally above normal in 1991 (figs. 13 and 14). Average area-weighted water levels rose slightly only in South Dakota and Wyoming. 
Table 8. Comparison of average annual water-level changes and departures of annual precipitation from normal for 1988 to 1992

\begin{tabular}{|c|c|c|c|c|}
\hline $\begin{array}{l}\text { Water-level-change } \\
\text { period }\end{array}$ & $\begin{array}{c}\text { Average } \\
\text { area-weighted } \\
\text { water-level change } \\
\text { (feet) }\end{array}$ & $\begin{array}{c}\text { Precipitation } \\
\text { year }\end{array}$ & $\begin{array}{c}\text { Average } \\
\text { area-weighted } \\
\text { departure of } \\
\text { precipitation from } \\
\text { normal }^{1} \text { (inches) }\end{array}$ & Data source \\
\hline 1988 to 1989 & -0.65 & 1988 & -0.17 & Dugan and others, 1990 \\
\hline 1989 to 1990 & -.63 & 1989 & -2.01 & Dugan and Schild, 1992 \\
\hline 1990 to 1991 & -.42 & 1990 & +.27 & McGrath and Dugan, 1993 \\
\hline 1991 to 1992 & -.55 & 1991 & +1.98 & This report \\
\hline $\begin{array}{l}\text { Annual average } 1988 \\
\text { to } 1992\end{array}$ & -.56 & $1988-91$ & +.02 & \\
\hline
\end{tabular}

${ }_{1}^{1951-80}$ area-weighted average annual (normal) precipitation $=19.01$ inches.

Table 9. Average area-weighted water-level changes from 1991 to 1992

\begin{tabular}{lc}
\hline \multicolumn{1}{c}{ State } & $\begin{array}{c}\text { Average area-weighted } \\
\text { water-level change (feet) }\end{array}$ \\
\hline Colorado & -0.20 \\
Kansas & -1.13 \\
Nebraska & -.47 \\
New Mexico & -.33 \\
Oklahoma & -.43 \\
South Dakota & +.08 \\
Texas & -.61 \\
Wyoming & +.11 \\
High Plains & \\
\hline
\end{tabular}

Table 10. Average area-weighted precipitation in 1991 and departure from 30-year normal (1951-80) [data from U.S. Department of Commerce. National Climatic Data Center, Asheville, North Carolina]

\begin{tabular}{lcc}
\hline \multicolumn{1}{c}{ State } & $\begin{array}{c}\text { Average area-weighted } \\
\text { preclpitation } \\
\text { (inches) }\end{array}$ & $\begin{array}{c}\text { Average area-weighted departure } \\
\text { from 30-year normal } \\
\text { (inches) }\end{array}$ \\
\hline Colorado & 18.99 & +2.37 \\
Kansas & 20.30 & -.32 \\
Nebraska & 20.96 & +.12 \\
New Mexico & 22.59 & +7.74 \\
Oklahoma & 19.22 & +.71 \\
South Dakota & 23.07 & +4.68 \\
Texas & 23.04 & +5.18 \\
Wyoming & 16.92 & +3.09 \\
High Plains & & +1.98 \\
\hline
\end{tabular}




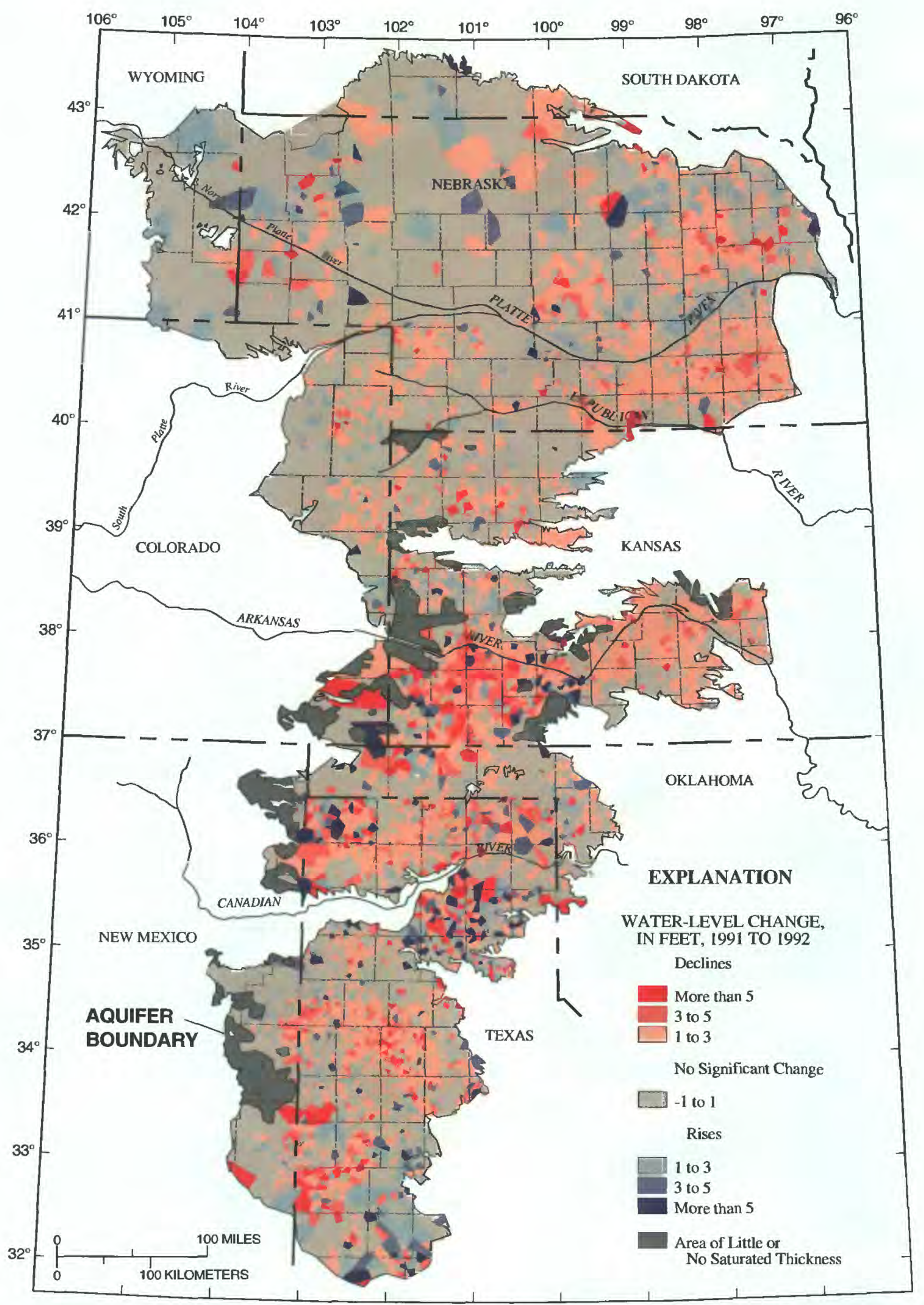

Figure 13. Water-level change in the High Plains aquifer, 1991 to 1992. 


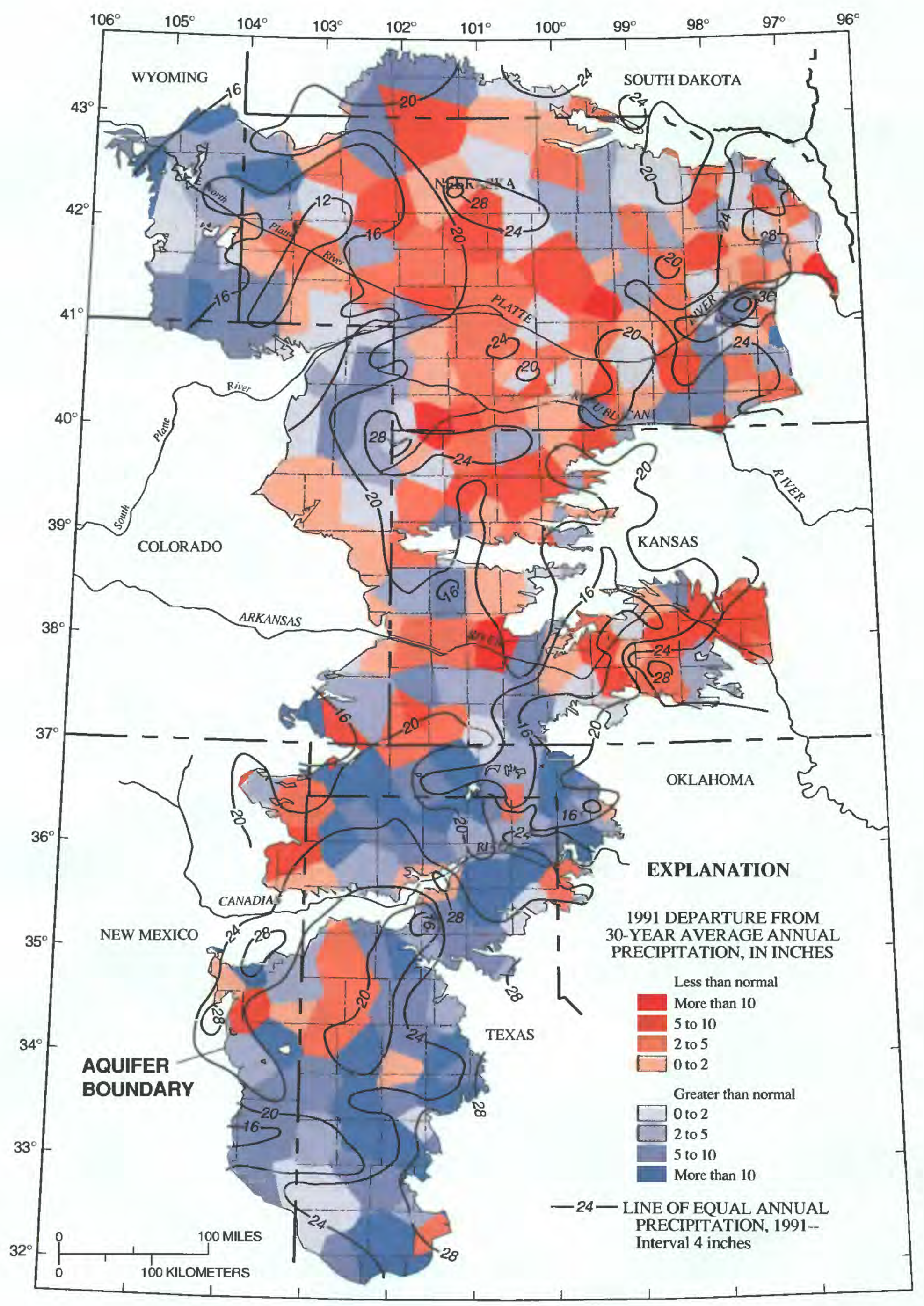

Figure 14. 1991 precipitation and departure from 30-year normal (1951-90) (precipitation data from National Climatic Data Center, 1951-91). 
Regional Water-Level Changes

\section{Northern High Plains}

Water levels in the Northern High Plains declined in most areas of extensive ground-water irrigation (fig. 13). Declines of 1 to 3 feet were widespread throughout the eastern part of the High Plains in Nebraska with declines exceeding 3 feet in a few small areas. Precipitation was quite variable in this area in 1991, ranging from wellabove normal in a few areas to well-below normal in other areas (fig. 14). There appears to be minimal correlation between water-level change and 1991 precipitation in most of these areas.

Another area of water-level decline in the Northern High Plains from 1991 to 1992 was in northeastern Colorado, southwestern Nebraska, and northwestern Kansas where irrigation is extensive. These declines were generally 1 to 3 feet but exceeded 3 feet in isolated areas, mainly in northwestern Kansas. This area of declines of 1 to 3 feet from 1991 to 1992 , however, is slightly smaller than the area of equivalent declines from 1990 to 1991 (McGrath and Dugan, 1993).

Precipitation in this area varied from as much as 5 to 10 inches above normal in northeastern Colorado to as much as 5 to 10 inches below normal in northwestern Kansas. There does not appear to be a close relation between 1991 annual precipitation and 1991 to 1992 water-level change. In large parts of this area, local regulations that limit pumping and development of additional irrigated land and encourage irrigation management practices appear to have had some effect on controlling further water-level declines.

Water levels from 1991 to 1992 declined in scattered areas of south-central South Dakota, the Nebraska Panhandle, and southeastern Wyoming (fig. 11). The areas of decline tended to coincide with areas where 1991 annual precipitation was near normal to below normal (fig. 14). These areas of decline included an intensively irrigated area in Box Butte County, Nebraska, where water levels generally rose from 1990 to 1991 (McGrath and Dugan, 1993) after almost continuous declines since the early 1950's.

Water levels generally rose in small, isolated areas of the Northern High Plains. Rises of 1 to 3 feet occurred in an area of intensive ground-water irrigation in Hall, Merrick, and Polk Counties, Nebraska, in the lower Platte River Valley (fig. 13). Annual precipitation in 1991, however, ranged from well-above to well-below normal in this area. Water levels also rose in discontinuous areas of northeastern Nebraska, generally in areas where 1991 annual precipitation was slightly above normal. Rises in water levels were common in the northern part of the Panhandle of Nebraska and in southeastern Wyoming in areas where 1991 precipitation was much above normal.

\section{Central High Plains}

Water-level declines from 1991 to 1992 in the extensively irrigated areas of the Central High Plains are in areas of large, nearly continuous declines since predevelopment (fig. 7). The area of largest declines was in southwest Kansas extending into the central Panhandle of Oklahoma, where declines of 3 to 5 feet were widespread (fig. 13). Smaller, discontinuous areas within this area had declines exceeding 5 feet. Precipitation in southwestern Kansas and the Oklahoma Panhandle in 1991 was variable, ranging from well-above to well-below normal (fig. 14). The patterns of waterlevel decline do not appear to reflect the annual precipitation patterns.

Another area in the Central High Plains with a continuation of water-level declines was the northern Panhandle of Texas and parts of northeastern New Mexico. These declines were generally from 1 to 3 feet from 1991 to 1992, with declines exceeding 3 feet in isolated areas. Annual precipitation in 1991 was as much as 10 inches above normal in much of this area, which may have reduced the magnitude of declines. Precipitation, however, was well-below normal in a small area of northeastern New Mexico and the extreme northwestern Texas Panhandle, and water levels generally declined 3 to 5 feet.

Precipitation in 1991 in much of the southern half of the Central High Plains was more than 5 inches above normal, but this did not result in substantial areas of water-level rise. Complex patterns of water-level change were evident from 1991 to 1992 in an area including Carson, Gray, Hutchinson, and Roberts Counties in the central Panhandle of Texas south of the Canadian River. Large, localized declines were often adjacent to 
areas of large, localized rises. These mixed patterns of water-level change also were evident in previous years (Dugan and Schild, 1992; McGrath and Dugan, 1993) and possibly represent an area where some irrigation pumpage may be occurring during the observation period, such as winter irrigation of wheat.

\section{Southern High Plains}

Two contrasting trends continued in the Southern High Plains from 1991 to 1992. Widespread water-level declines that began as early as 1940 with the development of groundwater irrigation in the northern part of the Southern High Plains continued from 1991 to 1992. These declines were generally from 1 to 3 feet, with some areas showing declines of 3 to 5 feet (fig. 13). Annual precipitation in 1991 was extremely variable in the northern part of the Southern High Plains, ranging from more than 10 inches above normal to more than 10 inches below normal (fig. 14). There appears to be no observable relation between the patterns of water-level decline and precipitation in this area.

The long-term trend of rising water levels continued in the extreme southeastern part of the Southern High Plains. Rises of 1 to 5 feet were common in this area and exceeded 5 feet in isolated areas. Precipitation in 1991 was as much as 10 inches or more above normal in large parts of the area where rises occurred. The area of 1 - to 3-foot rises from 1991 to 1992 appears to be substantially larger than the area of comparable rises from 1990 to 1991 (McGrath and Dugan, 1993), which may be attributable to the well-above normal precipitation in 1991.

Some of the areas where water-levels rose from 1990 to 1991 in the central and southern parts of the Southern High Plains (McGrath and Dugan, 1993) had declines from 1991 to 1992 that exceeded 5 feet in some areas. The largest area of these declines included parts of Gaines, Terry, and Cochran Counties, Texas, and Lea County, New Mexico. These declines do not appear to be related to annual precipitation, which was well-above normal throughout the area (fig. 14). A small area on the border of Gaines County, Texas, and Lea County, New Mexico, which has been an area of nearly continuous declines since predevelopment, had water-level declines generally exceeding 5 feet from 1991 to 1992.

\section{HYDROGRAPHS OF REPRESENTATIVE OBSERVATION WELLS}

The hydrographs in this report (figs. 15-22) illustrate water-level changes through time in selected observation wells in the High Plains (fig. 1). These wells generally are located in areas of substantial ground-water development and water-level change. Criteria for specific observation-well selection include: (1) wells that represent water-table conditions, (2) long-term observation wells that reflect, as close as possible, water-level changes that are due to long-term ground-water development from predevelopment to 1992 , and (3) observation wells at which multiple water-level measurements are made each year. Many of these wells are equipped with continuous water-level recorders, but only observations at selected time intervals are used to contrast the hydrographs.

The hydrographs include the following information pertaining to each well: (1) well depth, (2) surface elevation at the well, and (3) a well number that uniquely identifies the well in the USGS National Water Information System computer files. All hydrographs use the same scale interval ( 20 feet) to facilitate comparisons among hydrographs.

The varying responses of the different observation wells generally represent the effects of local patterns of ground-water development on water levels in a given area. The hydrographs of some observation wells, however, may indicate certain characteristics of the observation well itself or highly localized properties of the aquifer that are not typical of the area. In addition, the hydrograph trace of those wells with continuous recorders is generally more irregular than wells without continuous recorders because of the more numerous observations. 


\section{Colorado}

The hydrograph for an observation well in Yuma County (fig. 15A) is representative of the large water-level declines that have occurred in an area of substantial irrigation development in northeast Colorado since the mid-1960's. Waterlevel declines began in this well in the mid-1960's and have been continuous except for a brief period of rise in the late 1980's. Water-level declines from 1964 to 1992 were nearly 45 feet. From 1968 to 1980, water levels declined about 2 feet per year. Between 1980 and 1991, the rate of decline averaged about 1 foot per year. This decrease in the rate of decline likely is a result of an increase in precipitation and a decrease in the rate of withdrawals for irrigation. Water levels in this well, however, declined nearly 10 feet from 1991 to 1992, which may indicate pumping of a nearby well during the observation period in 1992 rather than a permanent decline.

The hydrograph for the well in Washington County (fig. 15B) indicates that long-term water- level changes were small in this area of the High Plains; water levels declined only about 3 feet from 1958 to 1992 . The annual variability reflects yearly differences in precipitation and pumpage. The observation well is located in an area where saturated thickness is less than $\mathbf{5 0}$ feet, well yields are small (less than 500 gallons per minute), and irrigation development is limited. The fluctuations in the hydrograph indicate that irrigation may be intermittent in this area. The slight rise in water levels in this well from 1980 to 1992 occurred in spite of below-normal precipitation during 1981-91 in this area.

The hydrograph of the well in Kit Carson County (fig. 15C) is typical for wells used for winter irrigation of wheat, a practice common throughout much of the western High Plains. The downward spikes are indicative of pumpage just prior to late-December or January measurements. From 1970 to 1992 , the water level in this well has declined about 12 feet or approximately 0.5 foot per year (E.R. Banta, in Dugan and Schild, 1992, p. 31-32). 


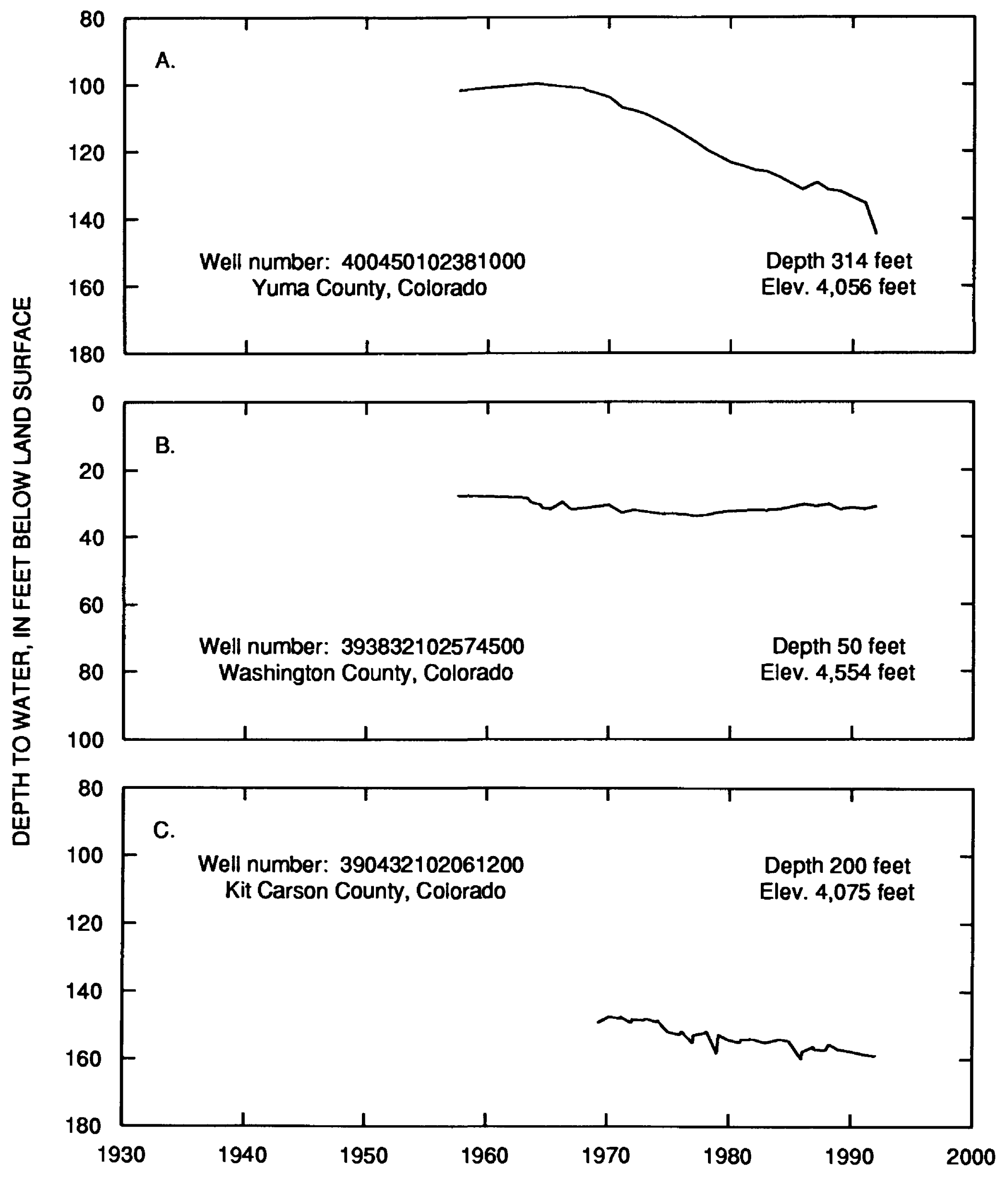

Figure 15. Water levels in observation wells in: $A$, Yuma County; $B$, Washington County; $C$, Kit Carson County, Colorado. 


\section{Kansas}

The hydrograph of the well in Thomas County (fig. 16A) shows a continual decline in water levels that corresponds to an increase in irrigation in the county following the drought of 1953-57. Total declines from about 1955 to 1992 were about 16 feet or slightly more than 0.4 foot per year. The water levels were generally stable from about 1981 to the mid-1980's in response to above-normal precipitation and a decline in the rate of irrigation development. From 1987 to 1992, water levels again declined at a slightly more rapid rate as a result of increased irrigation withdrawals during a period of below-normal precipitation.

The hydrograph of the well in Finney County (fig. 16B) is indicative of the overall decline of water levels since the early 1950's in this area of extensive irrigation development. Following World War II and the introduction of large-capacity turbine pumps, irrigation developed rapidly in this part of southwestern Kansas until the mid-1970's. From the early 1950's until the early 1980's, water levels in this well declined more than 40 feet, an average decline of nearly 1.5 feet per year. Since 1980, however, above-normal precipitation, decreases in irrigated acreages, and declines in pumpage rates have resulted in additional water-level declines of only about 10 feet in this well or about 0.8 foot per year.

The well located in Sedgwick County (fig. 16C) is completed in the unconsolidated Equus beds, which are principally Pleistocene in age. This formation, which constitutes the eastern extension of the High Plains aquifer in southcentral Kansas, is used extensively for publicwater supplies in this area. Rapid rates of longterm natural recharge (fig. 4) in this area contribute to the generally stable long-term water levels in this well (L.J. Combs and B.J. Pabst, in Dugan and Schild, 1992, p. 34-36). 


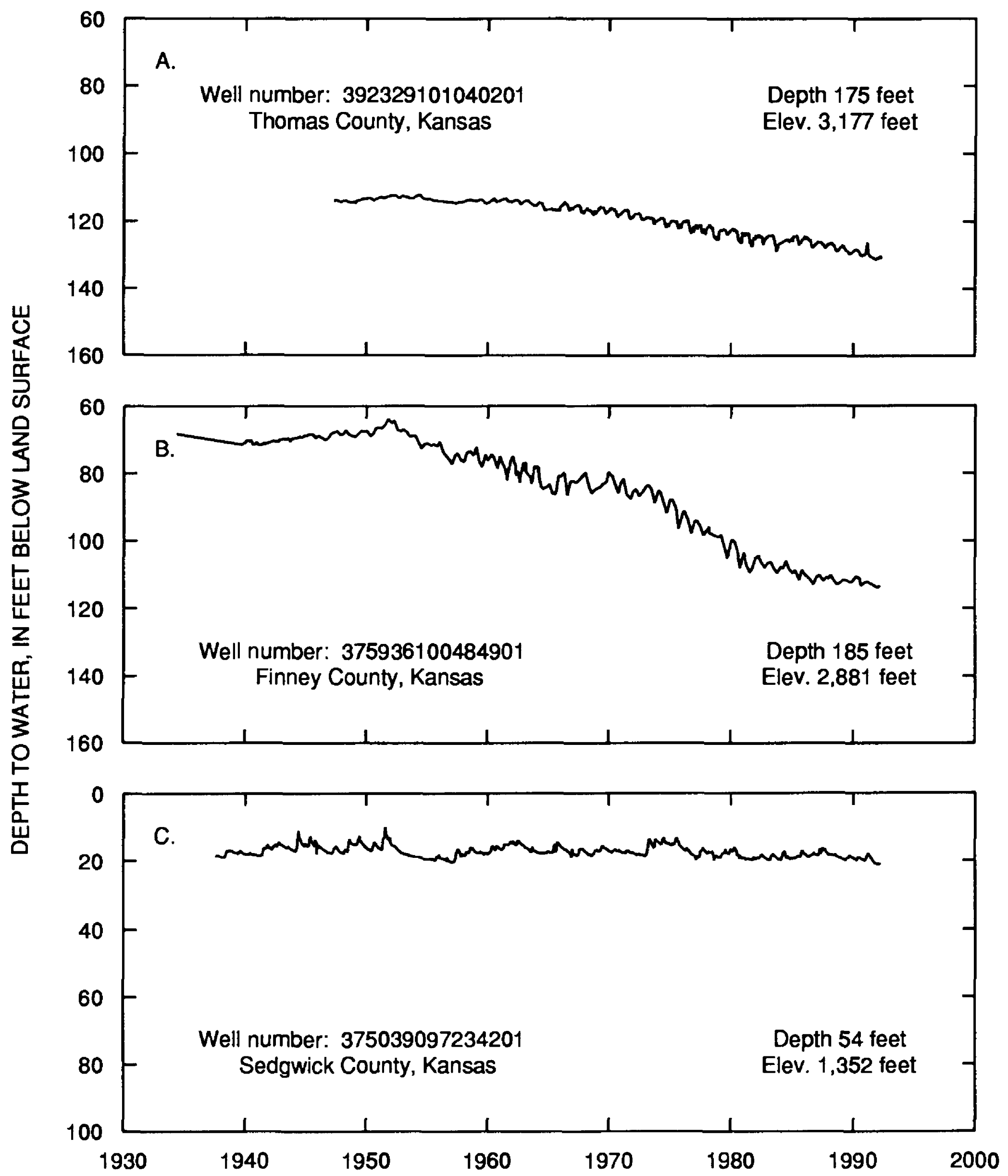

Figure 16. Water levels in observation wells in: $A$, Thomas County; $B$, Finney County; $C$, Sedgwick County, Kansas. 


\section{Nebraska}

The hydrograph of the well in Box Butte County (fig. 17A) represents the long-term waterlevel declines that have occurred in this area since the early 1950's. Water-level declines exceeded 42 feet from 1951 to 1992 or about 1 foot per year in this well, which is located in an area of intensive irrigation development. Limited recharge (fig. 3) and large consumptive irrigation requirements (fig. 5) as a result of small average annual precipitation (16 inches) in the area have contributed to these long-term declines.

The hydrograph of a well in Chase County (fig. 17B) represents the decline in water levels soon after substantial irrigation development began in southwestern Nebraska in the mid-1960's. Water levels declined about 38 feet from 1964 to 1992 or nearly 1.4 feet per year. Water levels rose slightly from 1980 to 1984 during a period of increased recharge and smaller consumptive irrigation requirements associated with much above-normal precipitation. Strict controls on annual irrigationwithdrawal rates and on the development of additional irrigated land were implemented in southwestern Nebraska in the late 1970's and apparently have contributed to slower rates of water-level decline since the early 1980 's. The hydrograph indicates the seasonal drawdown patterns of the water table associated with irrigation pumpage from nearby wells during the growing season. There are eight irrigation wells within 1 mile of the observation well. Seasonal drawdowns appear to have been greatest in the late 1970's, perhaps indicating the period of maximum pumpage in the surrounding area prior to implementation of ground-water controls.

The hydrograph of a well in Seward County (fig. $17 C$ ) represents water-level conditions in the extreme eastern High Plains of Nebraska from shortly after irrigation development began in the area in the mid-1950's. From 1963 to 1982 , water levels declined about 9 feet followed by waterlevel rises of about 12 feet from 1982 to 1988 when annual precipitation averaged about 32 inches or 6 inches above normal. Since 1988, annual precipitation in the area has averaged about 22 inches or more than 5 inches below normal, and water levels have declined about 5 feet. The water level in this well, however, declined less than 3 feet from 1959 to 1992, indicating large recharge (fig. 3) and small average consumptive irrigation requirements (fig. 5) during this period for this area. Seven irrigation wells are within 1 mile of the observation well and contribute to the pattern of seasonal drawdowns (J.T. Dugan, in Dugan and Schild, 1992, p. 38-40). 


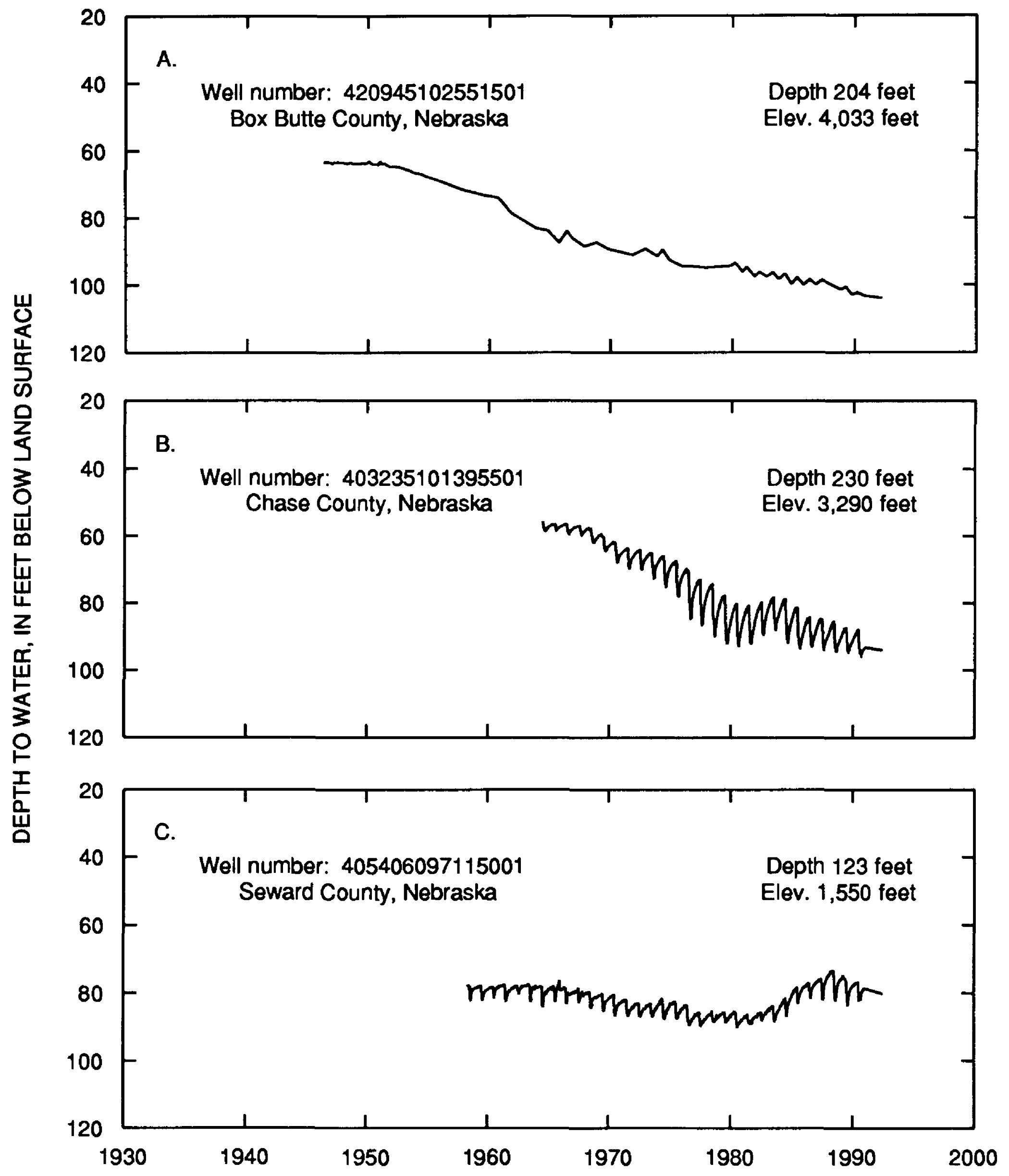

Figure 17. Water levels in observation wells in: $A$, Box Butte County; $B$, Chase County; $C$, Seward County, Nebraska. 


\section{New Mexico}

The hydrograph of an observation well in Union County in northeastern New Mexico (fig. 18A) represents an area of moderate irrigation development but very small average recharge (fig. 3) and large average consumptive irrigation requirements (fig. 5), which apparently have contributed to a steady decline in water levels in the area. Water levels in this observation well have declined about 16 feet since 1969. Substantial declines probably occurred in this area prior to the installation of this well (see fig. 7).

The hydrograph in figure $18 B$ represents an observation well in Curry County, just west of the intensively irrigated area in the northern part of the Southern High Plains of Texas and New Mexico. Water levels have declined steadily a total of about 16 feet in this well from 1961 to 1992--an average of 0.5 foot per year (R.R. Cruz, in Dugan and Schild, 1992, p. 41-42). 


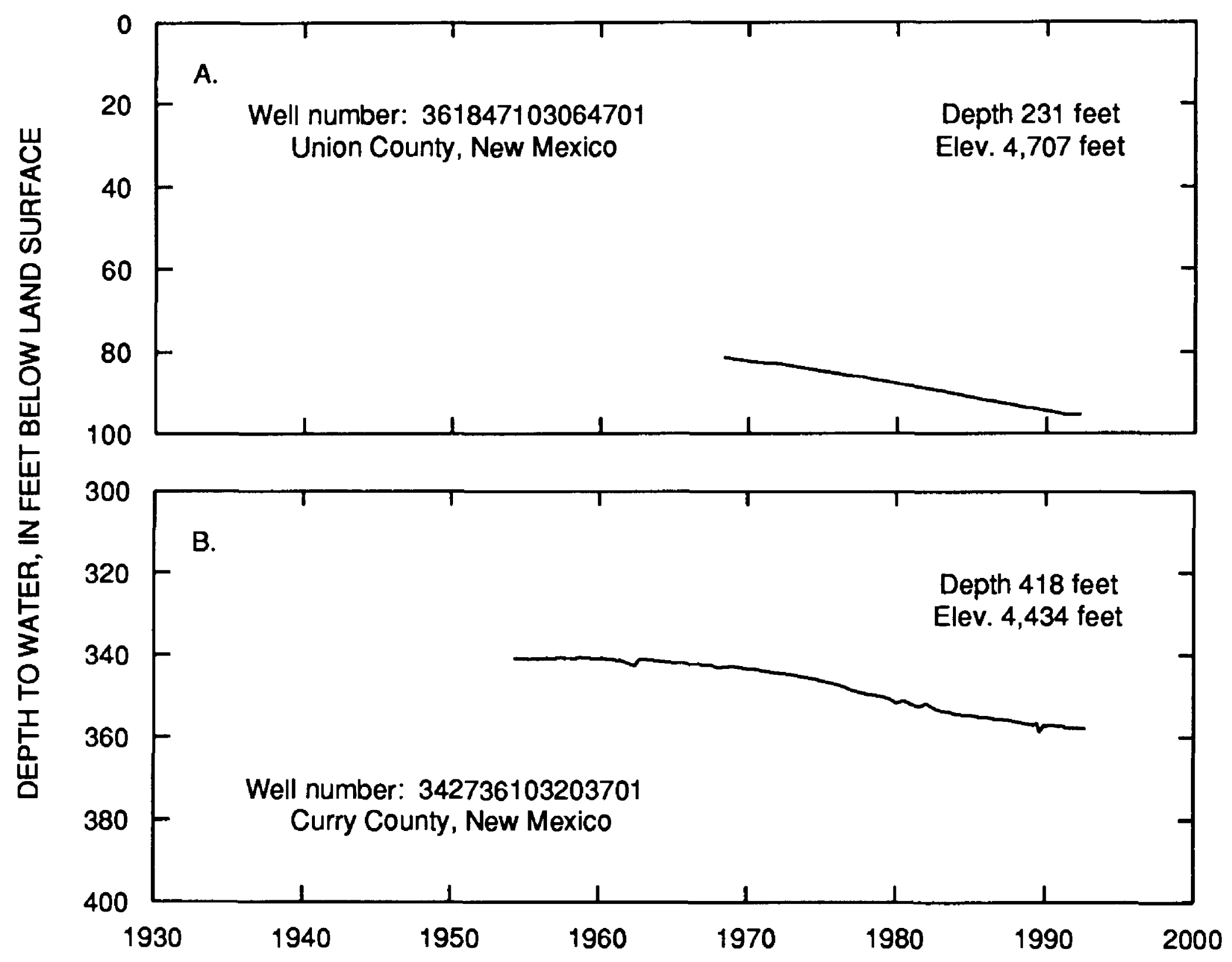

Figure 18. Water levels in observation wells in: $A$, Union County; $B$, Curry County, New Mexico. 


\section{Oklahoma}

The hydrograph of an observation well in Texas County (fig. 19A) shows a continual waterlevel decline totaling nearly 25 feet since the early 1960's. Most of this decline has occurred since about 1974. This observation well is located in Texas County on the southwestern edge of a large cone of depression in the water table. Water levels in the center of this cone declined about 100 feet from 1940 to 1980 (fig. 7). Declines in this well largely reflect the effect of long-term withdrawals for irrigation rather than short-term variability of precipitation in the surrounding area. The rate of water-level decline in the well began to increase in the early 1970's, reflecting an increase in acres irrigated that continued through 1981. A decrease in irrigated cropland since 1981 and a possible decrease in rates of withdrawals for irrigation in the 1980's as a result of above-normal precipitation appear to have slowed the rate of water-level decline in recent years. Irrigated acreage in Texas County decreased from a peak of nearly 190,000 acres in 1981 to less than 110,000 acres in 1990 (J.S. Havens, in Dugan and Schild, 1992, p. 43).

\section{South Dakota}

Net water-level change in a shallow observation well in Bennett County (fig. 20A) was minimal from 1960 to 1992 . These stable water-level conditions are indicative of the minimal irrigation development in this area. The upturn in the hydrograph in 1990 probably is related to the abovenormal precipitation in 1990 in this area. The water level declined slightly from 1991 to 1992 during a period when precipitation was well-below normal (fig. 12).

Water levels in an observation well in Tripp County in the eastern High Plains of South Dakota rose about 5 feet between the early 1980's and about 1990 (fig. 20B). This rise may be attributable to above-normal precipitation in 1981-90, which averaged about 23 inches annually or 3 inches above normal. Irrigation development is minimal in this area (J.R. Little and K.M. Neitzert, in Dugan and Schild, 1992, p. 45). Since 1990, water levels have declined slightly during a period of below-normal precipitation. 


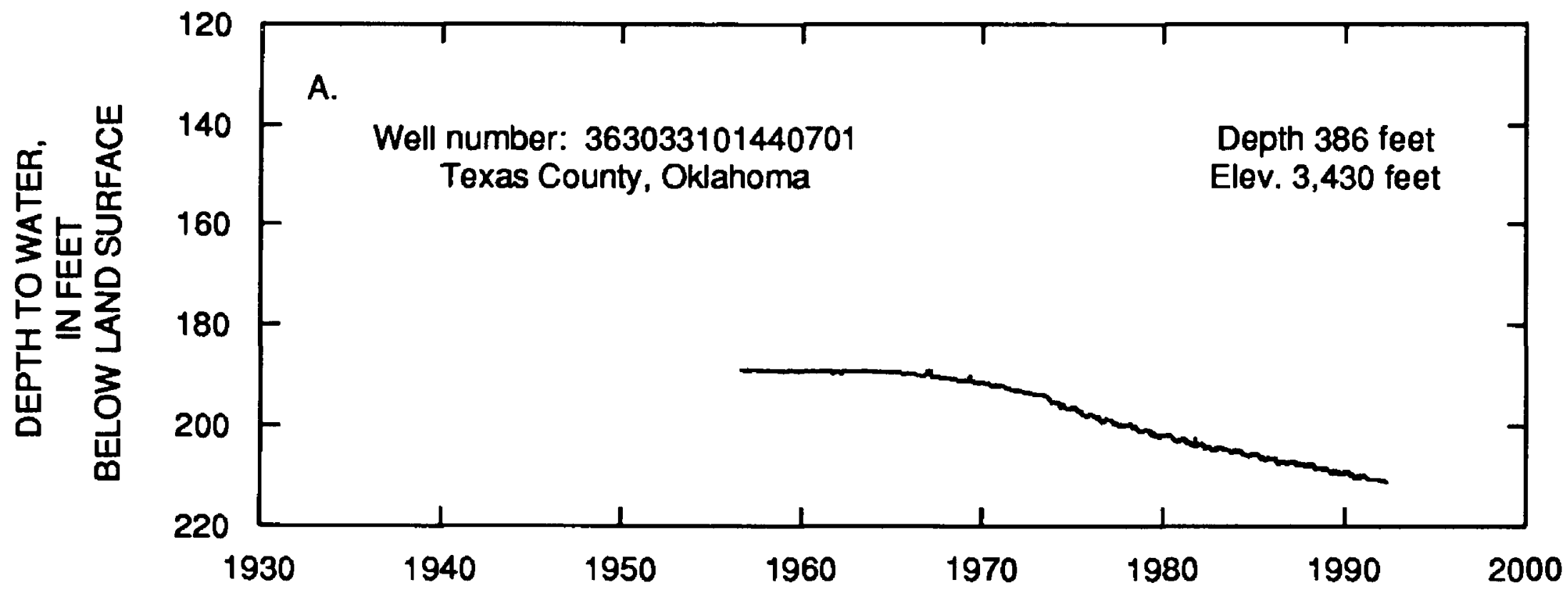

Flgure 19. Water levels in observation well in: $A$, Texas County, Oklahoma.

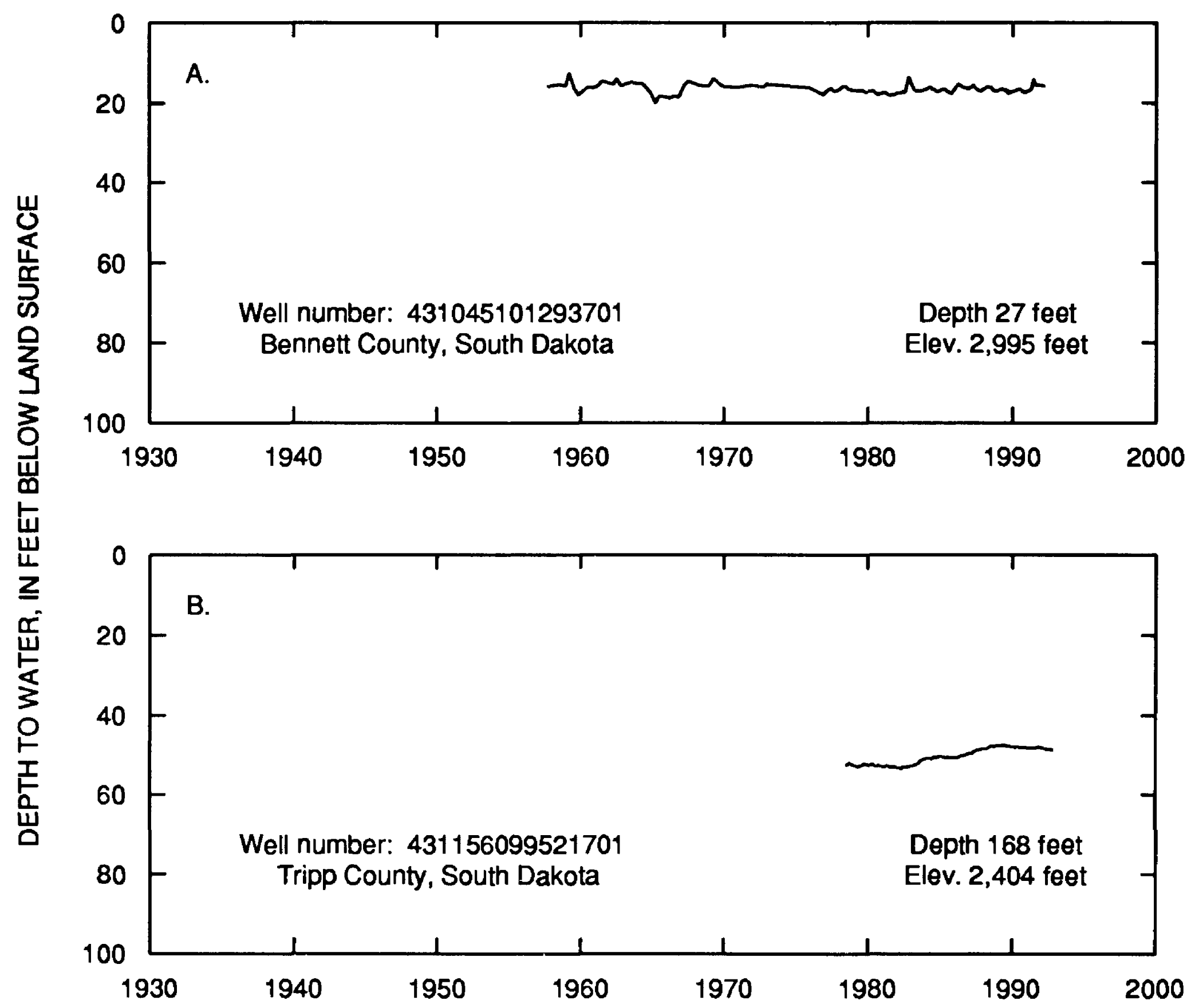

Figure 20. Water levels in observation wells in: $A$, Bennett County; $B$, Tripp County, South Dakota. 


\section{Texas}

The hydrograph for an observation well in Lamb County, Texas, illustrates the continuous depletion of the aquifer in the northern part of the Southern High Plains (fig. 21A). As a result of intensive irrigation withdrawals since the early 1950's, water levels had declined nearly 67 feet by 1992. Declines averaged about 3 feet per year from 1978 to 1986 and 2 feet per year after a period of stable water levels in 1986.

The hydrograph for an observation well in Lubbock County illustrates a unique condition (fig. 21B). Water levels began to rise in this well in the late 1960's after the City of Lubbock curtailed ground-water withdrawals and began to import water from outside the county. Ground-water withdrawals were curtailed further by a decrease in irrigation caused by the expansion of the city into previously irrigated farmland. Substantial amounts of recharge to the aquifer occur locally as a result of storm runoff, which collects in a large surface depression located in the southwestern part of the city. Although water levels rose nearly 30 feet between the late 1960's and 1992, declines of about 7 feet did occur in the well from 1988 to 1992.

The hydrograph for the well in Gaines County illustrates the rise in water levels in the southeastern part of the Southern High Plains (fig. 21C). Water levels in this well rose nearly 35 feet from 1969 to 1992 , about 30 feet of this rise occurring since 1982. Precipitation in this area averaged 4 to 6 inches above normal in 1981-91 (fig. 14). In addition, water levels in this area may have been affected by a rise in the potentiometric surface of the aquifer in the Cretaceous formation underlying the High Plains aquifer (J.B. Ashworth, in Dugan and Schild, 1992, p. 47-48). 

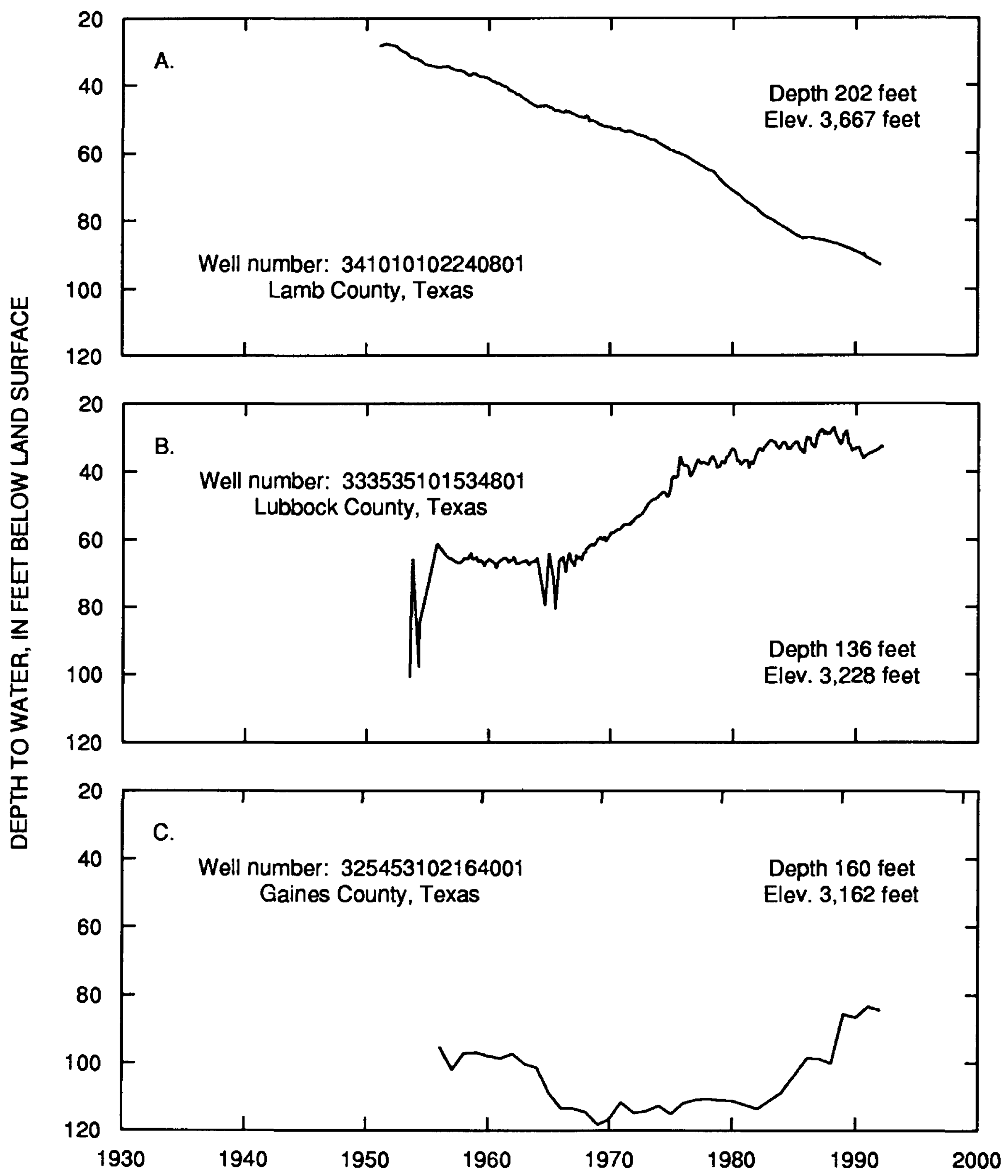

Figure 21. Water levels in observation wells in: $A$, Lamb County; $B$, Lubbock County; $C$, Gaines County, Texas. 


\section{Wyoming}

The hydrograph for a well in eastern Laramie County, near the Nebraska border, shows a rise of about 5 feet in the early 1980's but a net decline totalling nearly 4 feet from 1985 to 1992 (fig. 22A). Precipitation during 1981-91 averaged 2 to 4 inches above normal (fig. 14). The water-level decline in this well does not appear to be closely related to precipitation but to a possible increase in ground-water withdrawals in the surrounding area. The hydrograph indicates the well is very responsive to pumping of nearby wells, characterized by large, rapid drawdowns and recoveries.

Water levels in a well in southern Laramie County declined nearly 20 feet from 1974 to 1980 , rose nearly 15 feet from 1980 to 1986 , and declined about 3 feet from 1985 to 1992 (fig. 22B). The rise from 1980 to 1985 occurred during a period when precipitation averaged nearly 6 inches above normal. The declines from 1985 to 1992 , however, probably are related to an increase in pumpage in the surrounding area. During 1985-92, precipitation in the area averaged slightly above normal. Water levels in this well, however, rose more than 2 feet from 1991 to 1992, probably as a result of precipitation that was 5 to 10 inches above normal in 1992.

Water levels in a well in southern Niobrara County declined nearly 15 feet between 1973 and 1992, which is an average decline of about 0.8 foot per year (fig. 22C). The rate of decline was about 1.2 feet per year between 1973 and 1982, but only about 0.3 foot per year between 1982 and 1992. Precipitation from 1981 to 1990 was near normal or about 14 inches annually (fig. 11) (K.A. Miller, in Dugan and Schild, 1992, p. 50-51). 


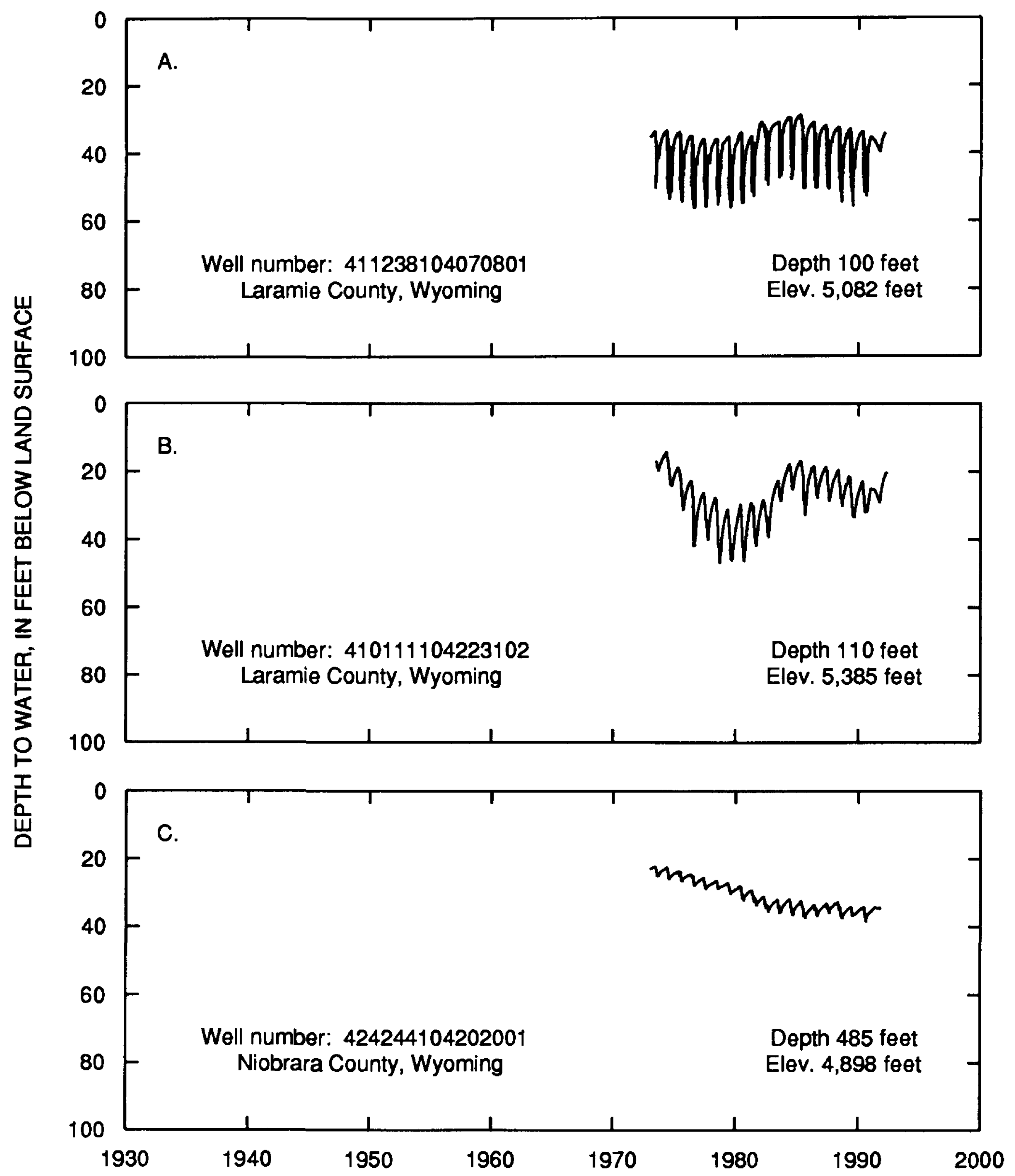

Figure 22. Water levels in observation wells in: $A$, eastern Laramie County; $B$, southern Laramie County; $C$, Niobrara County, Wyoming. 


\section{SELECTED REFERENCES}

Ashworth, J.B., 1991, Water-level changes in the High Plains aquifer of Texas: Texas Water Development Board Hydrologic Atlas 1, 1 sheet, scale 1: 250,000 .

Bevans, H.E., Spruill, T.B., and Kenny, J.F., 1985, Ground-water resources--Kansas, in National water summary 1984--Hydrologic events, selected water-quality trends, and ground-water resources: U.S. Geological Survey Water-Supply Paper 2275, p. 217-222.

Borman, R.R., 1983, Predevelopment and 1980 water table in the northern High Plains of Colorado, and water-level changes predevelopment to 1980 and 1975 to 1980: U.S. Geological Survey Hydrologic Investigations Atlas HA-670, 1 sheet, scale 1: $1,000,000$.

Carr, J.E., Chase, E.B., Paulson, R.W., and Moody, D.W., 1990, National water summary 1987-Hydrologic events and water supply and use: U.S. Geological Survey Water-Supply Paper 2350, $552 \mathrm{p}$.

Conservation and Survey Division, 1990, Center-pivot irrigation systems in Nebraska, 1988: University of Nebraska-Lincoln, Conservation and Survey Division map, 1 sheet, scale 1: 1,000,000.

Crist, M.A., 1983, Hydrologic evaluation of the Wheatland Flats area, Platte County, Wyoming: U.S. Geological Survey Water-Resources Investigations Report 83-4047, 36 p.

Cruz, R.R., 1990, Ground-water depletion, in feet, allowed in central and northern Lea, Roosevelt, and Curry Counties, New Mexico: New Mexico State Engineer, 4 sheets, scale 1: 100,000.

Dague, B.J., 1986, January 1986 water levels and data related to water-level changes, western and south-central Kansas: U.S. Geological Survey Open-File Report 86-317, 165 p.

Dick, E.N., 1975, Conquering the great American desert: Lincoln, University Nebraska Press, 456 p.

Dugan, J.T., Hobbs, R.D., and Ihm, L.A., 1990, Hydrologic characteristics of soils in the High Plains, Northern Great Plains, and Central Texas Carbonates regional aquifer systems: U.S. Geological Survey Hydrologic Investigations Atlas HA-714, 1 sheet, scale 1:3,168,000.

Dugan, J.T., and Peckenpaugh, J.M., 1985, Effects of climate, vegetation, and soils on consumptive water use and ground-water recharge to the Central Midwest regional aquifer system, mid-continent United States: U.S. Geological Survey Water-Resources Investigations Report 85-4236, $78 \mathrm{p}$.
Dugan, J.T., and Schild, D.E., 1992, Water-level changes in the High Plains aquifer--

Predevelopment to 1990: U.S. Geological Survey Water-Resources Investigations Report 91-4165, $55 \mathrm{p}$.

Dugan, J.T., Schild, D.E., and Kastner, W.M., 1990, Water-level changes in the High Plains aquifer underlying parts of South Dakota, Wyoming, Nebraska, Colorado, Kansas, New Mexico, Oklahoma, and Texas--Predevelopment through nonirrigation season 1988-89: U.S. Geological Survey Water-Resources Investigations Report 90-4153, 29 p.

Dugan, J.T. and Zelt, R.B., (in press), Simulation and analysis of soil-water conditions in the Great Plains and adjacent areas, Central United States, 1951-80: U.S. Geological Survey Water-Supply Paper 2427.

Ellis, M.J., Steele, G.V., and Wigley, P.B., 1990, Groundwater levels in Nebraska, 1989: University of Nebraska-Lincoln, Conservation and Survey Division Nebraska Water Survey Paper 67, 81 p.

Emry, R.J., Bjork, P.R., and Russell, L.S., 1987, The Chadronian, Orellan, and Whitneyan North American land mammal ages, in Woodburne, M.O., ed., Cenozoic mammals of North America: Berkeley and Los Angeles, University of California Press, p. 118-152.

Goeke, J.W., Peckenpaugh, J.M., Cady, R.E., and Dugan, J.T., 1992, Hydrogeology of parts of the Twin Platte and Middle Republican Natural Resources Districts, southwestern Nebraska: University of Nebraska-Lincoln, Conservation and Survey Division Nebraska Water Survey Paper 70, $89 \mathrm{p}$.

Gutentag, E.D., Heimes, F.J., Krothe, N.C., Luckey, R.R., and Weeks, J.B., 1984, Geohydrology of the High Plains aquifer in parts of Colorado, Kansas, Nebraska, New Mexico, Oklahoma, South Dakota, Texas, and Wyoming: U.S. Geological Survey Professional Paper 1400-B, 63 p.

Gutentag, E.D., Lobmeyer, D.H., and Slagle, S.E., 1981, Geohydrology of southwestern Kansas: Kansas Geological Survey Irrigation Series 7, 73 p.

Hansen, C.V., 1991, Estimates of freshwater storage and potential recharge for principal aquifers in Kansas: U.S. Geological Survey Water-Resources Investigations Report 87-4230, 100 p.

High Plains Underground Water Conservation District No. 1, 1990, District observation wells show one-foot average decline: Lubbock, Texas, The Cross Section, v. 36, no. 5, p. 1-8. 
Jensen, M.E., Robb, D.C.N., and Franzoy, C.E., 1970, Scheduling irrigation using climate-crop-soil data: Journal of the Irrigation Division, Proceedings of the American Society of Civil Engineers, v. 96, N.IR. 4, p. 25-38.

Kastner, W.M., Schild, D.E., and Spahr, D.S., 1989, Water-level changes in the High Plains aquifer underlying parts of South Dakota, Wyoming, Nebraska, Colorado, Kansas, New Mexico, Oklahoma, and Texas--Predevelopment through nonirrigation season, 1987-1988: U.S. Geological Survey Water-Resources Investigations Report 89-4073, $61 \mathrm{p}$.

Kennedy, H.I., and Green, S.L, 1990, Ground-water levels in Wyoming, 1980 through September 1989: U.S. Geological Survey Open-File Report 90-106, $132 \mathrm{p}$.

Lansford and others, 1990, Sources of irrigation water and irrigated and dry cropland acreages in New Mexico by county, 1987-89: New Mexico State University Agricultural Experiment Station Research Report 650, 54 p.

Lines, G.C., 1976, Digital model to predict effects of pumping from the Arikaree aquifer in the Dwyer area, southeastern Wyoming: U.S. Geological Survey Water-Resources Investigations, Open-File Report 8-76, 24 p.

Luckey, R.R., Gutentag, E.D., and Weeks, J.B., 1981, Water-level and saturated-thickness changes, predevelopment to 1980 in the High Plains aquifer in parts of Colorado, Kansas, Nebraska, New Mexico, Oklahoma, South Dakota, Texas, and Wyoming: U.S. Geological Survey Hydrologic Investigations Atlas HA-652, 2 sheets, scale 1: $2,500,000$.

Mackey, G.W., 1987, Comparison of irrigation pumpage and change in water storage of the High Plains aquifer in Castro and Palmer Counties, Texas, 1975-83: U.S. Geological Survey WaterResources Investigations Report 87-4032, 48 p.

Martner, B.E., 1986, Wyoming climate atlas: Lincoln, University of Nebraska Press, 432 p.

McGrath, Timothy, and Dugan, J.T., 1993, Water-level changes in the High Plains aquifer-- Predevelopment to 1991: U.S. Geological Survey WaterResources Investigation Report 93-4088, $53 \mathrm{p}$.

Morgan, A.M., 1946, Progress report on geology and ground-water resources of the Cheyenne area, Wyoming: Cheyenne, Wyo., U.S. Geological Survey open-file report, $55 \mathrm{p}$.

Morris, D.A., and Babcock, H.M., 1960, Geology and ground-water resources of Platte County, Wyoming: U.S. Geological Survey Water-Supply Paper 1490, $195 \mathrm{p}$.
National Climatic Data Center, 1951-91, Climatological data (by State): Asheville, North Carolina (published monthly).

Nebraska Department of Agriculture, 1992, Nebraska agricultural statistics, 1991-1992: Lincoln, Nebraska Department of Agriculture, $146 \mathrm{p}$.

Pabst, M.E., and Jenkins, E.D., 1976, Water-level changes in southwestern Kansas, 1940-75: Kansas Geological Survey Journal, May 1975, 26 p.

Peckenpaugh, J.M., and Dugan, J.T., 1983, Hydrogeology of parts of the Central Platte and Lower Loup Natural Resources Districts, Nebraska: U.S. Geological Survey Water-Resources Investigations Report 83-4219, $125 \mathrm{p}$.

Peckenpaugh, J.M., Dugan, J.T., Kern, R.A., and Schroeder, W.J., 1987, Hydrogeology of the Tri-Basin and parts of the Lower Republican and Central Platte Natural Resources Districts, Nebraska: U.S. Geological Survey Water-Resources Investigations Report 87-4176, $117 \mathrm{p}$.

Rapp, J.R., Warner, D.A., and Morgan, A.M., 1953, Geology and ground-water resources of the Egbert-Pine Bluffs-Carpenter area, Laramie County, Wyoming: U.S. Geological Survey Water-Supply Paper 1140, $67 \mathrm{p}$.

Schuetz, J.R., 1990, Wyoming water supply and use, in Carr, J.E., and others, compilers, National water summary 1987--Hydrologic events and water supply and use: U.S. Geological Survey WaterSupply Paper 2350, p. 539-544.

Solley, W.B., Pierce, R.R., and Perlman, H.A., 1993, Estimated use of water in the United States in 1990: U.S. Geological Survey Circular 1081, 76 p.

Steele, E.K., Jr., 1988, Estimated use of water in Nebraska, 1985: University of Nebraska-Lincoln, Institute of Agriculture and Natural Resources, Conservation and Survey Division, Nebraska Water Survey Paper 64, 125 p.

Stullken, L.E., Watts, K.R., and Lindgren R.J., 1985, Geohydrology of the High Plains aquifer, western Kansas: U.S. Geological Survey Water-Resources Investigations Report 85-4198, 86 p.

Sun, R.J., ed., 1986, Regional Aquifer-System Analysis Program of the U.S. Geological Survey--Summary of projects, 1978-84: U.S. Geological Survey Circular 1002, $264 \mathrm{p}$. 
Swinehart, J.B., 1989, Wind-blown deposits, in Bleed, Ann, and Flowerday, Charles, eds., An atlas of the Sand Hills: University of Nebraska-Lincoln, Institute of Agriculture and Natural Resources, Conservation and Survey Division, Resource Atlas 5, p. 45-56.

Tedford, R.H., Galusha, Theodore, Skinner, M.F., Taylor, B.E., Fields, R.W., Macdonald, J.R., Rensberger, J.M., Webb, S.D., and Whistler, D.P., 1987, Faunal succession and biochronology of the Arikareean through Hemphillian interval (late Oligocene through the earliest Pliocene Epochs) in North America, in Woodburne, M.O., ed., Cenozoic mammals of North America: Berkeley and Los Angeles, University of California Press, p. 153-210.

Texas Water Development Board, 1991, Surveys of irrigation in Texas--1958, 1964, 1969, 1974, 1979, 1984, and 1989: Texas Water Development Board Report 329, $125 \mathrm{p}$.

Thiessen, A.H., 1911, Precipitation averages for large areas: Monthly Weather Review, v. 39, p. 10821084.

Thornbury, W.D., 1956, Regional geomorphology of the United States: New York, John Wiley and Sons, $609 \mathrm{p}$.

U.S. Department of Commerce, 1951-91, Climatological data by State, monthly and annual summaries: Asheville, N.C., National Climatic Data Center.
U.S. Geological Survey, 1990, National water summary 1987--Hydrologic events and water supply and use: U.S. Geological Survey Water-Supply Paper $2350,553 \mathrm{p}$.

Van Slyke, G.D., and Joliat, S.A., 1990, Depletion of the Ogallala aquifer, northern High Plains designated ground water basin: Colorado Division of Water Resources, Office of the State Engineer, 14 p.

Weeks, J.B., and Gutentag, E.D., 1981, Bedrock geology, altitude of base, and 1980 saturated thickness of the High Plains aquifer in parts of Colorado, Kansas, Nebraska, New Mexico, Oklahoma, South Dakota, Texas, and Wyoming: U.S. Geological Survey Hydrologic Investigations Atlas HA-648, 2 sheets, scale 1: 250,000.

Weeks, J.B., Gutentag, E.D., Heimes, F.J., and Luckey, R.R., 1988, Summary of the High Plains regional aquifer-system analysis in parts of Colorado, Kansas, Nebraska, New Mexico, Oklahoma, South Dakota, Texas, and Wyoming: U.S. Geological Survey Professional Paper 1400-A, 30 p.

Whitcomb, H.A., and Cummings, T.R., 1965, Ground-water resources and geology of Niobrara County, Wyoming: U.S. Geological Survey Water-Supply Paper 1788, $101 \mathrm{p}$.

Wilson, Brian, 1986, Water use in New Mexico in 1985: New Mexico State Engineer Technical Report 46, $84 \mathrm{p}$. 